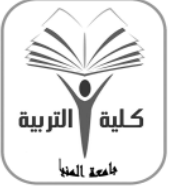

مجلة البعث في التربية وعلم النفس

كلية التربية - جامعة المنيا

كلية مُقتملةمن الميئة القومية لضمان جودةالتمليم

\title{
Using A Weblog-oriented Program for Promoting English Majors' Academic Writing and Authorial Identity
}

\author{
By
}

Dalia Ali Maher Abbass Mohammed

A Lecturer of TEFL Methodology, Dept. of Curriculum \& Instruction

Faculty of Education, Minia University

DOI: 10.21608/mathj.2019.82058

$$
\text { مجالة البجث في التربية ومام النفس }
$$

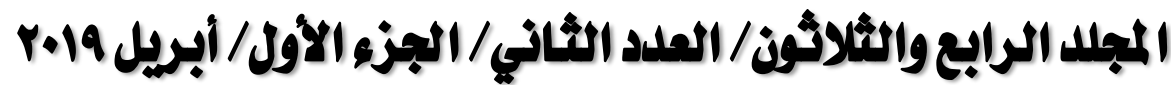

ISSN Print: (2090-0090)

ISSN Online: (2682-4469) 

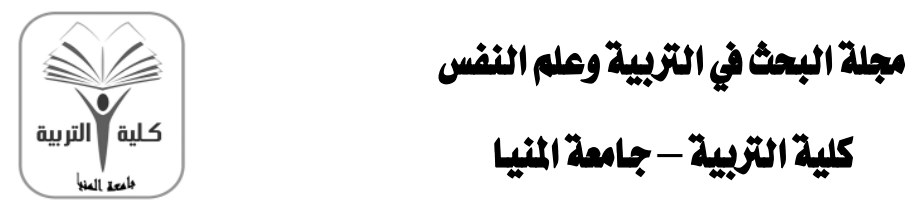

كاية التزبية - جامعة المنيا

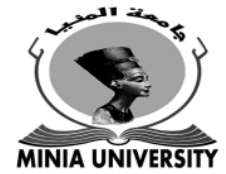

كلية مُعتمدة من الميئة القومية لضمان جودة التمليم

\section{Using A Weblog̉-0riented Program for Promoting English Majors' Academic Writing and Authorial Identity \\ By}

Dalia Ali Maher Abbass Mohammed

A Lecturer of TEFL Methodology, Dept. of Curriculum \& Instruction

Faculty of Education, Minia University

\section{Abstract}

The present study was conducted to investigate the impact of a program oriented towards using weblogs on promoting English majors' academic writing and their authorial identity. The study used the quasi-experimental research method (pre-post controlexperimental design). Sixty participants enrolled in the fourth year, English section at the Faculty of Education were randomly assigned to two intact groups: a treatment group $(n=30)$ and a non- treatment group $(n=30)$. The participants in the treatment group were trained and instructed using a program oriented towards weblogs whereas their counterparts in the non-treatment group did not receive such training as they received regular instruction. Instruments of the study included a language proficiency test, a needs- analysis survey of academic writing conventions, a questionnaire of academic writing skills, a test of academic writing and a scale of authorial identity. The findings revealed that the participants in the treatment group significantly surpassed their counterparts in the non-treatment group in the postperformance on the test of academic writing and the scale of authorial identity.

Key words: Weblogs, Academic Writing, Authorial Identity.

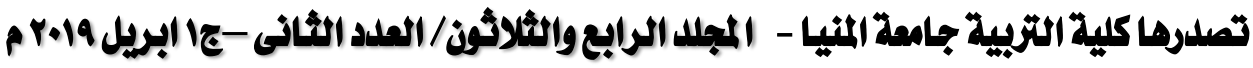




\section{كلية مُعتمدة من الميئة القومية لضمان جودة التمليم}

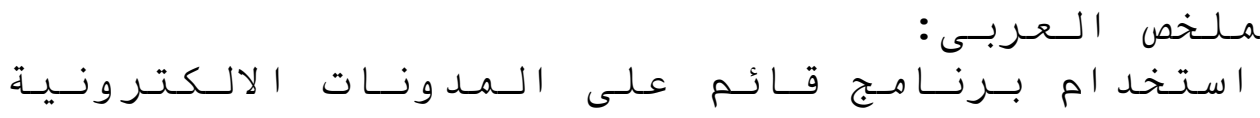

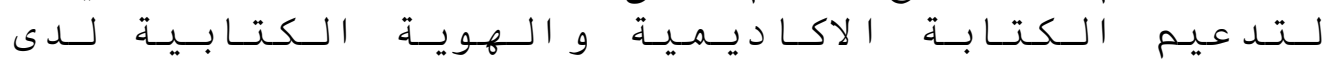

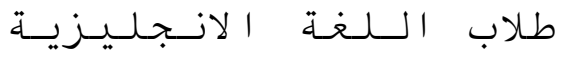

د/داليا على ماهر عباس محمد

مدرس المناهج وطرة تلريس اللفة الإنجيزية - كليه التزبية- جامعة المنيا

تم إجراء اللدراسة الحالية للتعرف على اثر استخدام برنامج قائم علي الملدونات الاككترونيه

فى تدعيه الكتابة الاكاديميه والهوية الكتابية للدى طلاب اللغة الانجليزية ـ ولقد ثم استخدام المنهج

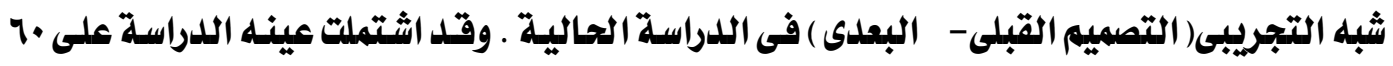
طالب و طالبه من طلاب الفرقة الرابعة بشعبه اللفة الإنجليزية بكليه التربية- جامعه المنيا ـ وقد تم

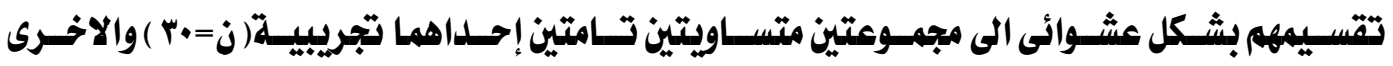
ضابطه (ن=×r ). ولقد تم تدريب الطلاب في العينة التجريبية بـاستخلام برنامج قائم على الملدونات الاككترونيه من تصميه الباحثة بينما استخدمت الطريقة المعتادة فى التدريس لطلاب العينة الضـابطة. وقد اشتملت أدوات اللدراسة على اختبار الكفاية اللفوية، استبيان لتحليد الاحتياجـات الخاصة بقواعل الكتابة الاكاديهي، استبيـان لمهارات الكتابة الاكاديميه ، اختبار الكتابة الاكاديميه، ، ومقيساس الهويلة الكتابية. وقد اظهرت النتائج تفوق أداء طلاب العينة التجريبية واللذى يفوق بـدوره اداء طلاب العينة

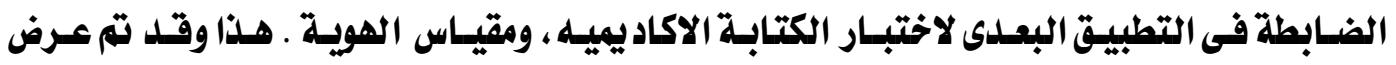
مناقشه و تفسير النتائج والتوصيات والمقترحات لأبحاث مستقبليه. الكلمات المفتاحية :الملدونات الاكتزونيه - الكتابه الاكاد يميه - المويه الكتابيه 

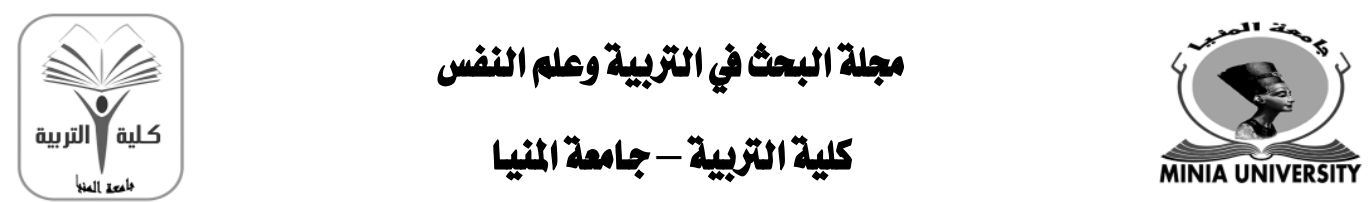

كلية مُعتملة من الميئة القومية لضمان جودة التمليم

\section{Introduction}

Within our lifetimes, we have seen the evolution of the webrelated technology and its emergence into a two- way medium as the second generation of the world wide web, web 2.0 technologies. Compared with Web 1.0 tools such as emails or traditional webpages, Web 2.0 applications are highly adaptable and promote greater degrees of interaction, collaboration and creativity. Through web 2.0 technologies, users are enabled to view the same static worksheets while adding video, audio comments, and questions as well as their own materials in synchronous or asynchronous discussions.

Web 2.0 tools are characterized with their ability to support a positive environment for language learning. They are widely used nowadays by almost everyone in the globe as means of communication. Moreover, the use of web technology has become a valid procedure in many areas of higher education where educators are experiencing a great degree of awareness and comfort with using technology. Educators are encouraging students to employ digital tools for research and writing, thus addressing the use of information and communication technologies for academic purposes as well as for socializing.

With this global dominance of technological advancement, it has become imperative that the teaching of English, specifically writing, must be interactive to make it more challenging and meaningful to the learners. The interactive nature of the Web makes it a good platform for the teaching of writing. Shank (2008, cited in Calvert 2014: 109) categorizes four educational changes resulting from the application of the World Wide Web: from takeit-when it's- offered to on-demand, from rote learning and repetition to collaborative construction of knowledge, from static facts to an endless amount of information, and from authoritative and dominating content to buyer beware information. The web

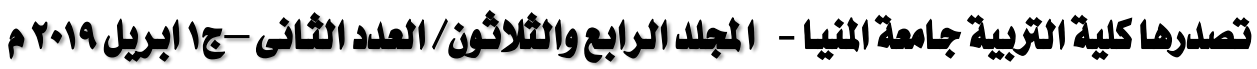

gamel_abdo59@yahoo.com

http://ms.minia.edu.eg/edu/journal.aspx 

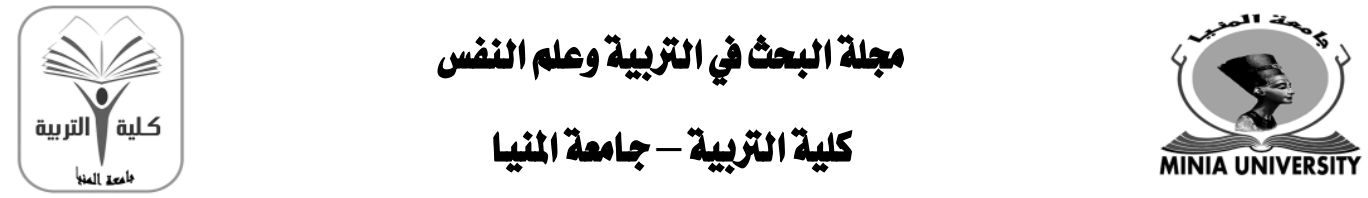

كلية مُعتمدة من الميئة القومية لضمان جودةالتمليم

challenges any centralized control of information as the students themselves can contribute to the information conversation.

Weblogs

Weblogs have been considered one of the most common applications in the Web 2.0 era. The term weblog is a contraction of two words: web and log. Weblogs are online journals that can be continuously updated by its users at their own pace without space and time constraints. They have become significant learning and social networking tools that can help individuals, groups, and organizations learn in new and interesting ways. They are different from other Wikis in that blogs are possessed and controlled by the bloggers and are mainly centered on authors themselves, rather than organized around specific topics. They, according to Chong (2010), have influentially affected the way we use the Internet, from mostly information consumers to information creators and contributors. Additionally, they are considered effective means of self-presentation, information exchange, and social networking.

Weblogs, according to Cequena (2013), are characterized by their strong personal editorship, hyperlinking and archival features as well as public access to content arranged chronologically in reverse order, where the recent post appears first. While most weblogs are textual, Aydin (2014) points out that a blog typically combines texts, images, videos and links to other blogs and focuses on specific areas such as art (artblogs), photographs (photoblogs), videos (videoblogs or vblogs), music (MP3blogs), audio (podcasts) or microblogs that feature very short posts.

Consequently, weblogs invite users to share, create, and interact in a virtual space - through writing and commenting on each other's posts - to generate knowledge where meaning served as the prominent focus rather than from encouraging reflection and meaning negotiation.

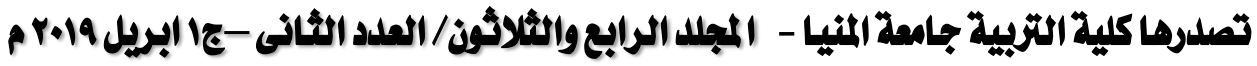

gamel_abdo59@yahoo.com

http://ms.minia.edu.eg/edu/journal.aspx 

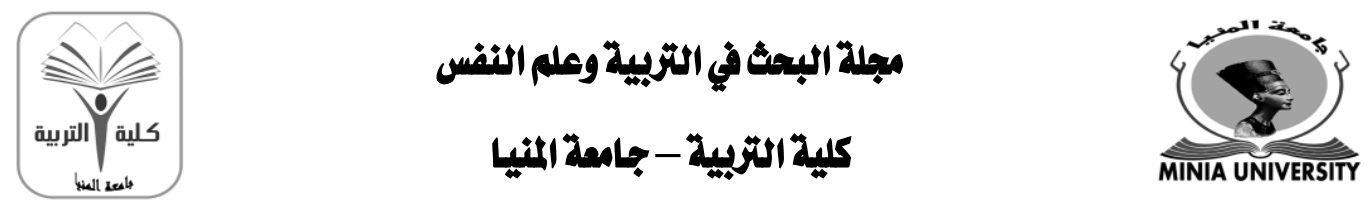

كلية مُتملةة من الميئة القومية لضمان جودة التمليي

In pedagogical contexts, blogs provide both teachers and learners with new horizons in the field of language teaching and learning. Through blogs, Arslan (2014) assures that both teachers and students have an authentic language environment to reach wider audiences to offer and share ideas and opinions collaboratively at every stage of writing. With the interactive nature of blogs, learners receive and give feedback to each other's writing in novel ways without the pressure of face to face comments or time restrictions. This scaffolding, as Calvert (2014) and Huang (2016) state, by more able students via commenting and revision may promote negotiation for meaning and facilitate deeper information processing.

Inside the classroom, according to Solomon and Schrum (2010, cited in Calvert ,2014:110) five characteristics make weblogs powerful tools. First, the brevity of weblogs forces students to communicate their ideas concisely. Meanwhile, the instantaneous nature of blogs allows quick publishing and feedback. In addition to brevity and speed, blogs can be enhanced with visual and multimedia elements, making them more attractive to readers. With their comment features, blogs allow students to interact and become more responsive to one another virtually beyond the classroom. Finally, the material exists forever, allowing for permanent portfolios of student work. Academic writing

English writing, in EFL contexts is considered the most challenging and the most critical skill for learners to master, particularly in free academic writing. This is due to the importance of considering both ideas as well as their logical organization. However, writing skills are crucial for all students, and in higher education specifically, for their future careers. Moreover, writing in a second or foreign language is more difficult than writing in the first language. This difficulty results from the need to learn new structural elements of the new

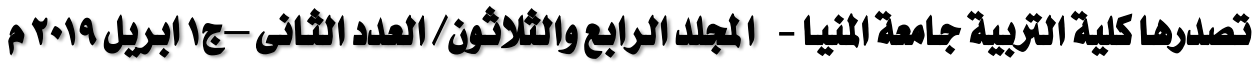

gamel_abdo59@yahoo.com

http://ms.minia.edu.eg/edu/journal.aspx 

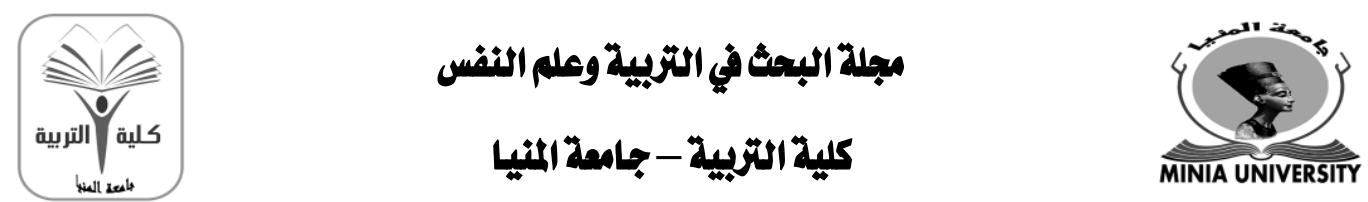

كلية مُعتمدة من الميئة القومية لضمان جودة التمعيم

language, new rhetorical conventions in addition to the appropriate organization of the final written-product. Therefore, many EFL college students consider English composition the most difficult skill to acquire. The sources of those students' struggle, as Aljumah (2012) and Huang (2016) argue, may result from their low proficiency in grammar, the interference between their first language and the English language in addition to their lower motivation for writing tasks and assignments.

Regardless of their major, university students are required to try different types of academic writing, such as term papers or exam answers, throughout their studies. Academic writing, which refers generally to all writing created for the purpose of study, has various types including theses, articles, papers, projects and posters. These types, as Alméciga and Evans (2014) emphasize, usually involve reporting a research process as a composition. With its wide range of types, academic writing is regarded as a discipline in itself. This discipline, according to Ángel and García (2017), requires mastery of advanced levels of grammatical forms and sophisticated vocabulary to interpret and produce different genre-based texts. Moreover, Akkaya and Aydin (2018) add that it contains different parts ranging from title writing to bibliography, and attributes of their writing that include language, expression and form.

Language has been characterized as culturally-bound. Marulanda and Martinez (2017) indicate that there are culturallydefined aspects of both spoken and written forms of language, such as genre, style, syntax. etc., which are constructed, shaped, and determined by the social use of the language. Consequently, language learners, as Haung (2016) and Marulanda and Martinez (2017) argue, need opportunities to gain writing competencies through trial and error, rather than through offering corrections, and through engagement in collaborative dialogues and discussions, rather than through instruction. Therefore, academic writing instruction, as Marulanda and Martinez (2017) and

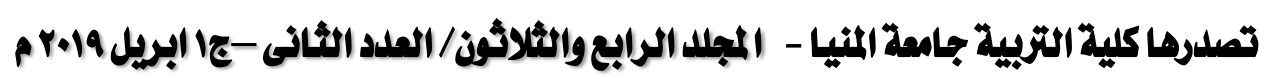



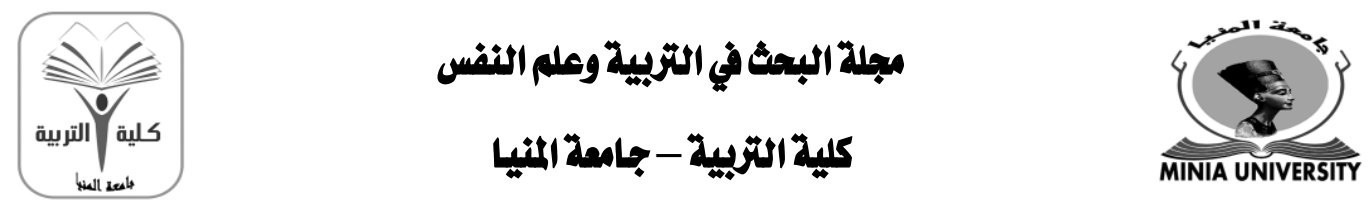

كلية مُعتمدة من الميئة القومية لضمان جودة التمليم

Akkaya and Aydin, 2018 emphasize, should be approached as a communicative process that focuses on tasks tackling form, meaning and function and involves a set of strategies such as drafting, organization, brainstorming, and revising, among others. Thus, writers would be enabled to learn to assimilate the practices of the community successfully and find their own voices within the community specific to their academic disciplines.

The dimensions of academic writing. Academic writing, as Bahar (2014, cited in Akkaya \& Aydin, 2018 :128) states, can be analyzed in four dimensions named as process, text, form and ethics. The process dimension contains the steps for reporting and publishing a specific subject on the basis of the audience to be addressed, and the intended results to be achieved through accessing different resources. The text dimension deals with being competent about written expression; spelling, punctuation, word selection, sentence structure and paragraph flow. As for the form dimension, it represents visual features, other than linguistic and stylistic features. It addresses the specified systematic order of presenting information, different citations and publication rules (font, line spacing, etc.) as applied by assigned journals. Then, the ethical dimension relates to the moral rules that researchers must follow regarding the data collection, synthesis, interpretation and publication of results. Likewise, these moral rules relate to avoiding plagiarism, acknowledging contributors, integrity and originality. Moreover, through academic writing, as Listyani (2018) assures, students would learn how to find mistakes or inconsistencies in others' arguments, how to formulate their own arguments and persuade others to agree with their opinions. Clear ideas in analysis, synthesis, and evaluation through consistent ideas and goad reasoning.

This general agreement on the importance of writing skill and the general disengagement of students in writing has provided the challenge for educators and researchers to look for ways to

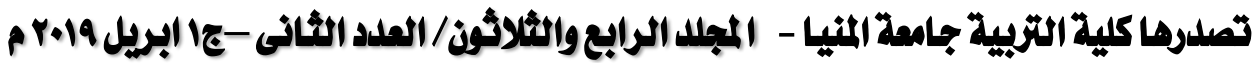

gamel_abdo59@yahoo.com

http://ms.minia.edu.eg/edu/journal.aspx 

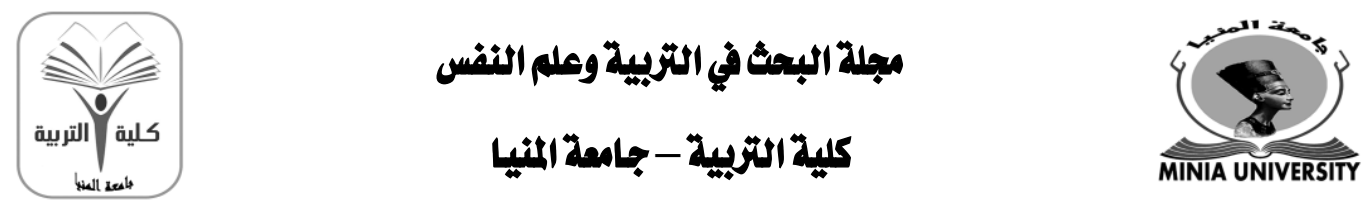

كلية مُعتمدة من الميئة القومية لضمان جودة التمليم

teach and motivate students to write effectively. Educators have attempted to find ways that do not cause a writer' block and motivate learners to continue learning even after class ends through appropriate and engaging environments. In recent years, consequently, researchers (Aljumah, 2012; Janks, 2012 and Haung, 2016) have shown an increased interest in writing instruction that occurs over the Internet. Researchers have emphasized that the use of recent innovations such as weblogs can motivate students to write and that their communication through words needs to be effective because their peers and the world are reading their writing.

Academic writing and blogging

The availability of a wide range of different social media platforms, such as Weblogs, Twitter or You Tube, for writing has enabled people to be involved with and learn the new writing genres associated with them. Since, working in online environments, as Thomson (2015) and McCullocha, Tustinga and Hamilton (2017) argue, challenges the established uses of language, the nature of academic identity, relationship with time, technological skills and ways of engaging in online practices, weblogs are used to encourage students to critically analyze academic texts as well as their own scholarly writing. Blogging, as Thomson (2015) and Senel (2018) point out, is in itself a kind of academic writing and academic publication.

The real payoffs of blogging, as Cequena (2013) and Thomson (2015) argue, for academic writing are:

- establishing writing as a routine. since weblog posts can be simple, short and easy to be prepared, published and enhanced through received feedback so it would lead to sustain a pattern of regular writing.

- leading bloggers to experiment with their writing voice. Since blogging can be informal, so bloggers can experiment, through

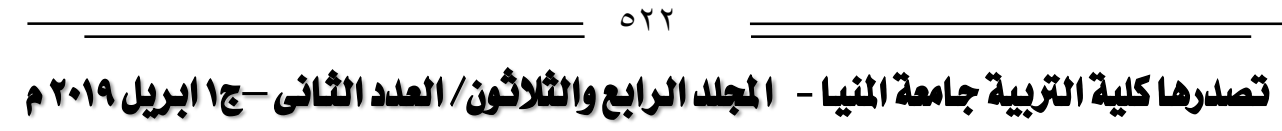



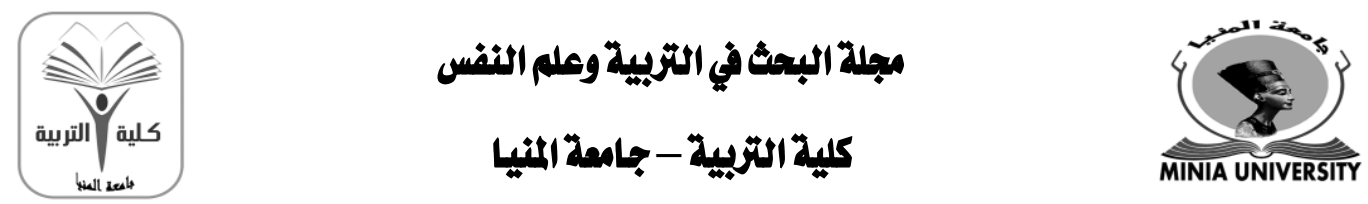

كلية مُعتمدة من الميئة القومية لضمان جودة التمليم

their blogposts, different types of syntax, vocabulary, genres till one can decide on the desired voice.

- considering readers in ways that are different from other academic writing publications as bloggers can keep track of the kinds of posts that are most likely to be read, by whom and where reading happens.

- learning to say something short can be practiced through blogs since blogs are directed towards brevity and being concise.

- allowing experimentation with forms of writing through the multi-media affordances of the blogging platform to include images, videos, slides and sound in their posts which may include reviews, descriptions, reflections or any other kind of writings.

- developing confidence in writing as being accustomed to blogpost and to see one's words published which would create a sense of ease in writing as well as confidence in one's capabilities to find a place out there in the world.

- providing bloggers with a sense of authorship through allowing them to reflect on the requirements of academic writing, the purposes of writing, and their authority as writers.

Academic writing and authorial identity

Over the past two decades conceptions of academic writing have shifted emphasis from acquisition of specific grammatical and linguistic skills to a social practice. Academic writing, according to Hyland (2002), is a variety of subject-specific literacies that displays considerable differences between disciplines. It involves interaction with the texts and people within one's discipline. This interaction, as Hyland (2002) and Inouye and McAlpine (2019) assure, involves adopting an appropriate identity.

Academic writing has been considered as an essential component for many coursework assessments and that graduate students should continuously develop their academic writing skills. Current research has related academic writing to a student's sense of self and identity (Hyland, 2002; Mastuda, 2015;

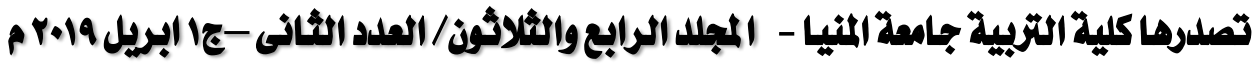

gamel_abdo59@yahoo.com

http://ms.minia.edu.eg/edu/journal.aspx 

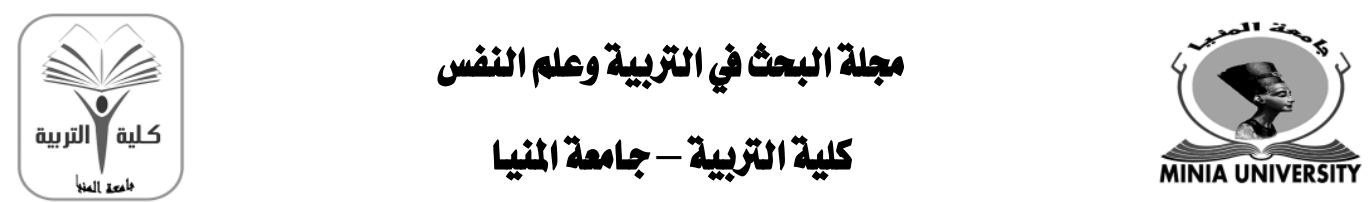

كلية مُعتمدة من الميئة القومية لضمان جودة التمليم

Singh, 2017; Hryniuk, 2018 and Inouye \& McAlpine, 2019). As a result of this, new graduate students not only need to know the rules and conventions of writing in a specific discipline but also should have a recognizable writer identity for participation in various academic writing practices. They have to identify themselves as part of a particular academic community, and without this identity formation, as Singh (2017) assures, they will not be able to acquire academic literacies skills linked to academic success.

A writer's authorial identity, or authorship is an integral element in academic writing and an essential component of writing pedagogy.

Academic identity or scholarly identity, according to Hyland (2002), is an act of identity that conveys the specific disciplinary content and also carries a presentation of the writer. Identity, as Crawford, Mora Pablo and Lengeling (2016) emphasize, is to a significant extent established, negotiated, and developed through discourse. Likewise, Singh (2017) points out that authorial identity refers to the way writers position themselves within their particular fields, draw upon and interact with other texts, make textual choices and exhibit the skills and thinking patterns that are typically attributed to independent authors and established academics.

The construction of identity in language users has been researched extensively in the past twenty years (Ivanic, 1998; Mustuda, 2015 and Hryniuk, 2018) and continues to be a significant topic to be researched. Ivanic (1998, cited in Mastuda, 2015: 143:144) pinpoints three aspects of writerly identity: (1) the autobiographical self that deals with the way writing is influenced by aspects of one's life history, ideas and beliefs through the issues a writer chooses to write about, (2) the discoursal self refers to the sense of the author that is conveyed in writing by drawing on certain discursive features that are associated with academic articles in the field, such as nominalization, use of hedges and boosters, reporting verbs, APA style citations, self-mention, and so on. The discoursal

تصدرها كالية التربية جامعة المثيا - المجلد الرابع والثالاثوذ/العدد الثانى -جا ابريل 19. م م

gamel_abdo59@yahoo.com

http://ms.minia.edu.eg/edu/journal.aspx 

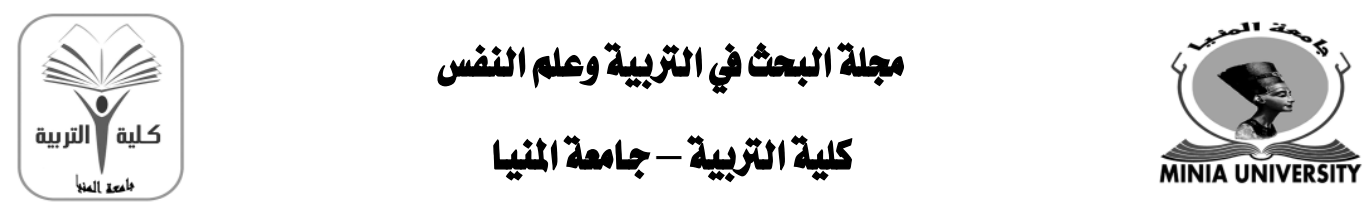

كلية مُعتمدة من الميئة القومية لشمان جودة التمليم

self is also created through nondiscursive features, such as the choice of topic, the points of emphasis in the discussion, and the attention to the style, genre and citation conventions of a discipline, (3) the authorial self is the degree to which writers establish presence in their texts, relating to their opinions, beliefs, position and (4) the selfhood that refers to the social aspects of identities which differ from one social context to another.

Likewise, Matsuda (2015) points out that identity is not optional; all texts says something about the writer, although some are more marked than others. Matsuda (2015) and Crawford et al. (2016) indicate that identity in written discourse involves both empirical reality that can be described and measured (e.g., demographics and textual features) and phenomenological reality that exists in people's perceptions (e.g., social constructs). Consequently, they add that novice writers must acquire new genres with all their characteristics in addition to constructing new academic writer identities under a strong influence of the local, socio-cultural context in which they write. In other words, learning and identity are inseparable and can be thought of as the same phenomenon.

Weblogs, academic writing and authorial identity

Writing is not just a matter of reproducing knowledge, but rather a means of creating knowledge and constructing identity that involves social and cognitive factors. Accordingly, Luehmann (2008) suggests that online learning environments, more generally, may offer professionals unique affordances to promote identity development. Weblogs, specifically, enables individuals to express their thoughts at their own pace and in their own space. Consequently, Pinkman (2005) and Luehmann (2008) assume that blogging becomes communicative and interactive when participants assume multiple roles in the writing process, (e.g. writers who write and post, readers/reviewers who respond to other writers' posts, etc.). In fact, the act of blogging, according to

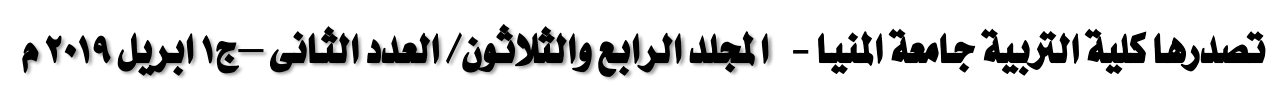

gamel_abdo59@yahoo.com

http://ms.minia.edu.eg/edu/journal.aspx 

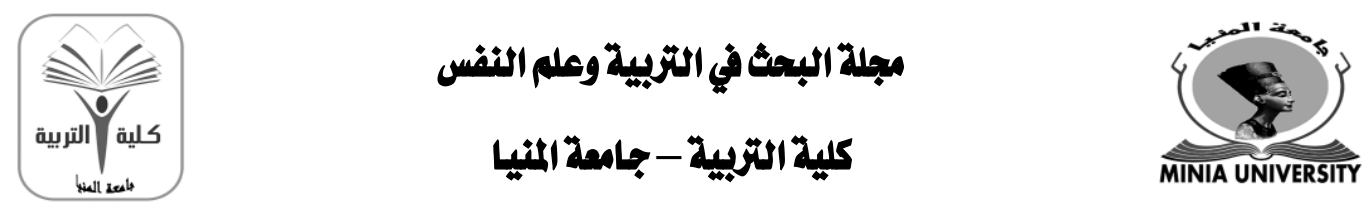

كلية مُعتمدة من الميئة القومية لضمان جودة التمليم

Sun and Chang (2012), rather than Wikis or listservs, gives the students a sense of authorship as the writers of the blog entries and, at the same time, provides a space for them to begin to identify what accounts for being an author and its associated responsibilities.

More specifically, Luehmann (2008) and Sun and Chang (2012) pinpoint the role of weblogs in promoting authorial identity in academic writing contexts: (1) they allow for self-direction as each blogger is enabled to determine the focus and purpose of the writing as well as the method, (2) they provide rich opportunities for reflection and meta-cognition through ongoing and thoughtful writing and reflection. Through weblogs, thinking becomes visible and available for critique and comment by oneself as well as others, (3) they invite perspective making and -taking through interacting with an audience. Authoring blogs involves engaging in two simultaneous conversations: one with the self and one with others that can encourage new ideas, and (4) they allow for knowledge brokering as through blogging features and cultural practices (e.g. embedded hyperlinks), bloggers would be encouraged to select and connect their own work and thoughts to those of others, thus taking the role of knowledge brokers.

The demands of writing tasks at the college level require more sophisticated levels in the argumentative and interpretive dimensions of language. Thus, according to Ángel and García (2017), these teachers in development need to learn the language of the academia represented in the advanced levels of grammatical forms and sophisticated vocabulary to interpret and produce different genre-based texts. Since, authorship honors the voices of all students, which is more important now than ever, so all students should be guided towards an awareness of the options that academic writing offers. Consequently, educators need to support and empower students to write, to edit, and to share their work with others through combining traditional pedagogical strategies (readings and paper assignments) with electronic

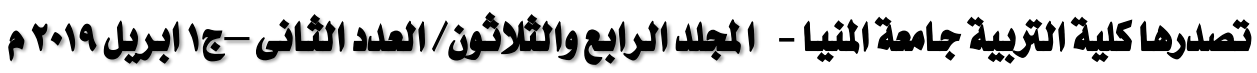

gamel_abdo59@yahoo.com

http://ms.minia.edu.eg/edu/journal.aspx 


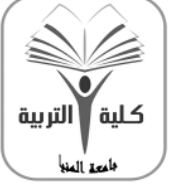

$$
\text { مجالة البعث في التزبية وملم النفس }
$$

$$
\text { كلية التربية - جامعة المنيا }
$$

كلية مُعتمدة نن الهيئة القومية لشمان جودة التعليم

pedagogical strategies (e.g.weblogs) to increase opportunities for significant discourse and interaction about culture and identity. 

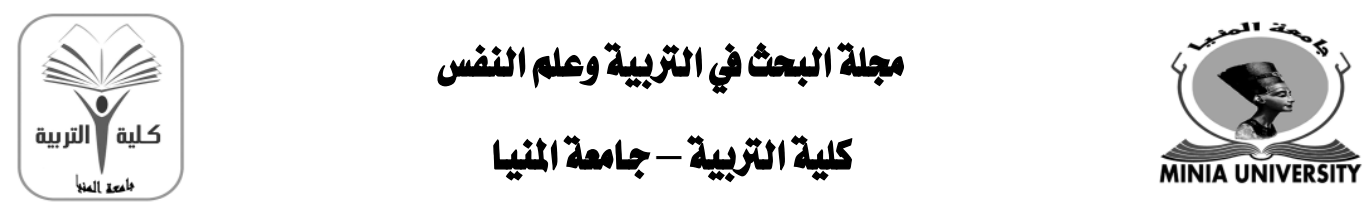

كلية مُعتمدة من الميئة القومية لضمان جودة التمليم

\section{Context of the problem}

Most EFL students, literally practice how to make sentences in English by translating and memorizing English idioms in schools. In college, the core activities in English composition courses, include dialogue memorization, grammar and structured pattern drills. Writing seems to be generally taught as a mechanical skill with tutors focus mainly on course requirements and use most of the class time for test preparation instead of assisting with writing skills through appropriate constructive feedback. Even though some teachers' self-efficacy in teaching EFL writing at the college level is high, their feedback on student papers is limited to grammar correction rather than rephrasing awkward sentences and commenting on content or organization. Consequently, without an understanding of writing as a social interaction and social construction, many students usually end up producing texts only to meet the expectations of their instructors.

More specifically, writing an effective academic paper in English can be a daunting experience for most EFL students because academic writing is a complex skill and a real challenging process. Proper academic writing competence needs awareness of all the lexical and syntactical knowledge focusing on contextualization and the various aspects of writers' characteristics. Moreover, relying on the native language resources cannot prevent making structural and meaning-based mistakes as what is considered logical in one culture may not be in another. Since academic writing competence is considered the most important element in achieving future academic success, so acquiring academic writing skills is highly emphasized. In addition, there is a need for a more integrating image of authorial identity in English academic writing addressing the writer, the text, the writing context as well as outsiders (e.g. teachers, readers).

To be more specific, the researcher submitted a questionnaire of academic writing skills to the senior students at

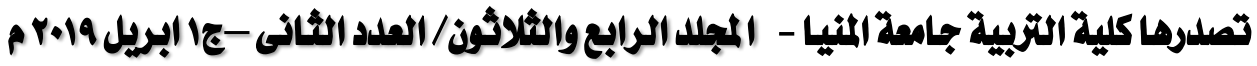

gamel_abdo59@yahoo.com

http://ms.minia.edu.eg/edu/journal.aspx 

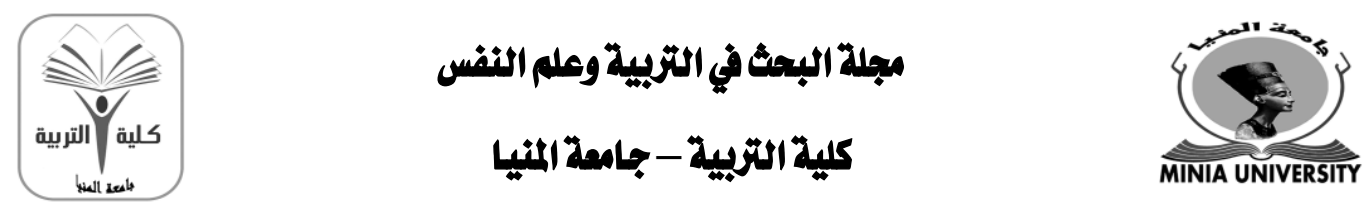

كلية مُعتمدة من الميئة القومية لضمان جودة التمليم

the English section at the Faculty of Education, Minia University to identify the present status of their academic writing skills. The responses of the participants revealed the high degree of their lack of confidence in their abilities to write. The majority of the participants did not consider themselves writers with very limited skills in either presenting themselves in their writing or even using their own words in their expression. It is true that the majority of the participants reported a high level of their background knowledge of English conventions. However, most of them reported their lack of any knowledge of referencing systems in English with dominating preferences of direct quoting over restating or paraphrasing of the materials used. Though, they assured their urgent needs for help when writing generally and most specifically during academic tasks, they indicated the very few times of receiving appropriate feedback that could help them improve their writing skills or overcome their first language interference problems.

Thus, there is a need for explicit discussion of the dominant discourse in the academy in the tertiary level. Focused and explicit writing instruction would help students raise their awareness of the relationship among language, identity, and the knowledge behind the available discourses (Hyland, 2002; Janks, 2012 and Kim, 2017). Also, the careful selection of teaching materials, important resources and motivating teaching/learning activities can guide learners to use linguistic resources confidently in order to construct positive academic writer identities (Pittam et al., 2009). So, integrating the three domains (cognitive, social, and textual) that shape a more balanced representation of the writing ability with a web related- technology would promote learners' academic writing with their abilities to express their authorial voice. Review of related literature Theoretical background

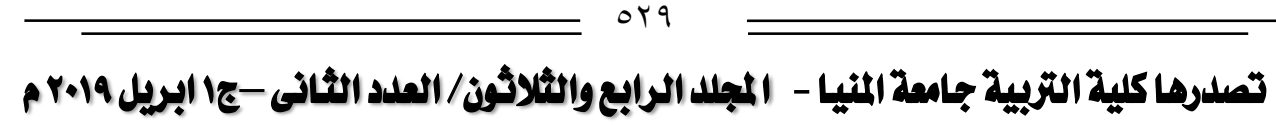



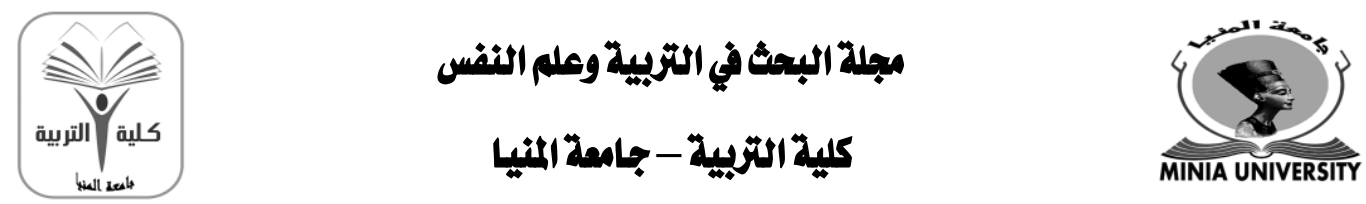

كلية مُعتمدة من الميئة القومية لشمان جودة التمليم

The theoretical approaches guided the current study are represented in the theory of constructivism (Brooks \& Brooks, 1993 and Wilson, 1996). On the basis of cognitive constructivism, as Sun and Chang (2012) and Hryniuk (2018) argue, academic writers use language in their texts to acknowledge and construct the presence of the author and interact socially with the reader. According to the view of social constructivists of identity (e.g. Vygotsky), learners can achieve and internalize new skills with the help of experts, language teachers and/or other mediational means, such as artifacts and language in a zone of proximal development (ZPD), which can be significant factors in the construction of writer identity.

Likewise, the weblogs, as Sun and Chang (2012) and Qiyuan (2013) argue, may be regarded as constructivist learning environments, for they provide their users with opportunities to reflect on their experiences and negotiate ideas with their readers. Moreover, the use of weblogs, draws on Swain's (2000) conceptualization of collaborative dialogue. Blogs, as Bruke (2011)and Sun and Chang (2012) clarify, can be considered as learning spaces that nurture such collaborative interaction, scaffold learning and facilitate tracing learners' paths of knowledge processing, construction, and identity negotiation.

Moreover, academic writing practices are thought to be guided by the academic literacies model (ALM) (Lea \& Street, 1998 and 2006).This model, according to Singh (2017), focuses on academic writing practices from the perspective of the students rather than the educators giving more voice to the students through their collaborative efforts to align their academic writing practices to the expected practices in their current educational institution and the socio-cultural aspects of the academic community. Moreover, the classroom activities, she adds, are crucial elements in disciplinary enculturation as they induct students into a particular discipline such as lectures, doing or.

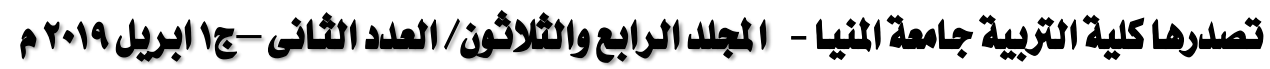

gamel_abdo59@yahoo.com

http://ms.minia.edu.eg/edu/journal.aspx 

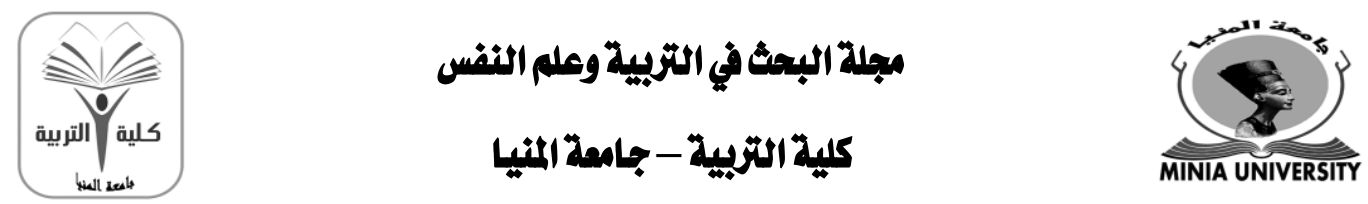

كلية مُعتمدة من الميئة القومية لضمان جودة التمليم

reading, lecturers' feedback, and especially writing through which the success of academic performance is decided.

Related studies

Reviewing literature revealed that it has shed light on the ways weblogs can be used to encourage language learning and learners' participation in writing practices (Cequena, 2013; Qiyuan, 2013; Arslan, 2014; Calvert, 2014 and Namouz et al., 2017), to increase interest and motivation to use English (Aljmah, 2012), to create a more relaxed, student-centered and self-paced language environment (Aljmah, 2012 and Vurdien, 2012), to develop self-reflection and peer-feedback through collaborative skills (Vurdien, 2012), to increase authenticity in both learning and teaching of English writing (Kitchakran, 2014 and Huang, 2016), to develop academic writing knowledge (Aydin, 2014; Kim, 2017 ; McCullocha et al. 2017and Akkaya \& Aydin, 2018) and the sense of their writer identity (Sun \& Chang, 2012 and Inouye \& McAlpine, 2019).

However, little empirical research has been done to examine how weblogs can enable EFL graduate students develop academic writing knowledge and writer identities (Chong, 2010; Sun \& Chang, 2012; Namouz, Misher-Tal \& Sela, 2017 and Scott et al. 2018). More specifically, concerning academic writing, the results of previous research have assured that academic writing, is not a uniformly faceless, rigid and meaningless form of writing, displays considerable differences between disciplines (Hyland, 2002; Aljmah, 2012 and Cennetkuşu, 2017).

Concerning the aspect of authorial identity, results of previous studies referred to the cultural differences among various countries (English vs. Spanish vs. Chinese) (Hyland, 2002), the unequal power relationship between novices and experts (thesis writers vs. examiners) (Wu \& Zhu, 2015 and Jarkas \& Fakhreddine, 2017), a lack of assertiveness on the part of the writers, and unwillingness to assume responsibility for their claims (Eldaba , 2018; Hryniuk, 2018

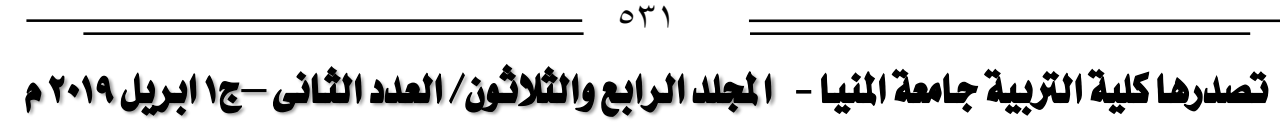



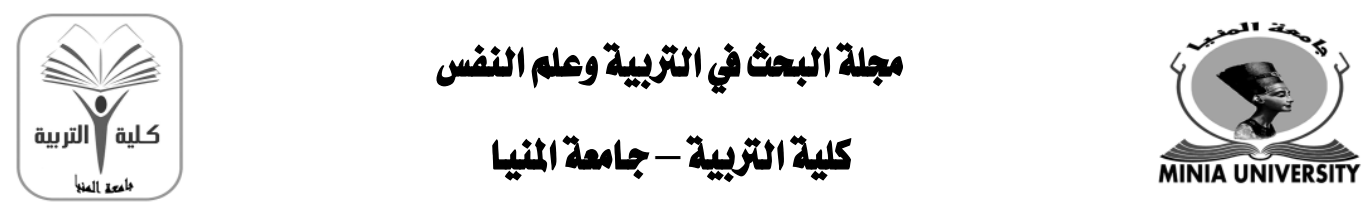

كلية مُعتمدة من الميئة القومية لضمان جودة التمليم

and Yang, 2018) as the reasons for either the downplay of or sustaining authorial identity among L2 writers (Muñoz, 2013 and Yang, 2018). Other studies emphasized that sharing one's writing can be used as a means to further examine the writer's identity (RankinBrown \& Fitzpatrick,2007) and that reducing unintentional plagiarism can be done through improving students' authorial identity (Pittam et al. 2009).

Moreover, there has been great emphasis in the previously conducted studies that explicit instruction in academic writing conventions is highly important in promoting the development of writers' authorial identity (Burke, 2011; Janks, 2012; Cheung, et al., 2016 ; Ghufron et al., 2016; Jarkas \& Fakhreddine, 2017; Hryniuk, 2018 ; Listyani, 2018 and Inouye \& McAlpine, 2019). Thus, on the basis of the previous studies, the present study sought to investigate the impact of using weblogs on the promotion of EFL senior students' academic writing and authorial identity.

Statement of the problem

Effective academic writing incorporates options of expressing meaning as well as giving impressions of writer's identity as a result of appropriate language choices. Since problems of language proficiency always seem to be more urgent and common, so teachers tend to focus their efforts on helping students manage the presentation of their information before managing their presentation of themselves. However, the interpersonal aspects of writing should not be considered as extra options. Moreover, the management of writer's identity should not be postponed till students gain control of summarizing, synthesizing, handling citations, and so on as both aspects are central to academic argument and university success.

Thus, the teacher's role is to develop learners' awareness of the importance of managing the content of their writing as well as the effects of self-mention. This can be done through creating

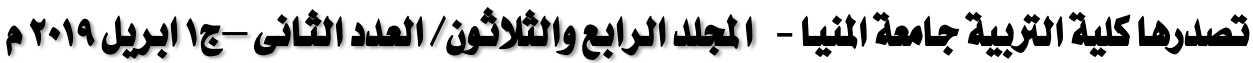

gamel_abdo59@yahoo.com

http://ms.minia.edu.eg/edu/journal.aspx 

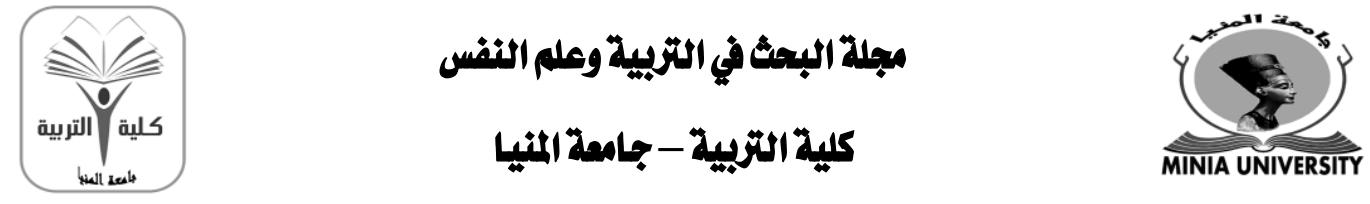

كلية مُعتمدة من الميئة القومية لضمان جودة التمليم

appropriate tasks within a suitable web-related technology environment (weblogs) for students to create and reinvent their authorial voices and identities. Consequently, learners will be better able to gain control over their writing and meet the considerable challenges of academic writing in another language. Hence, this study comes as an attempt to investigate the impact of weblog-oriented program on promoting English majors' academic writing and authorial identity.

Questions of the study

The present study attempted to answer the following questions:

1. What is the effect of using a weblog oriented-program on promoting English majors' academic writing?

2. What is the effect of using a weblog oriented-program on promoting English majors' authorial identity?

Purposes of the study

The current study attempted to identify:

1. the effect of using a weblog- oriented program on promoting English majors' academic writing.

2. the effect of using a weblog- oriented program on promoting English majors' authorial identity.

Hypotheses of the study

The present study attempted to test the following hypotheses:

1. There would be a statistically significant difference between mean scores obtained by the participants of the treatment and the non-treatment groups on the post- performance on the test of academic writing (favoring the treatment group).

2. There would be a statistically significant difference between mean values obtained by the participants of the treatment and the non-treatment groups on the post- performance on the scale of authorial identity (favoring the treatment group).

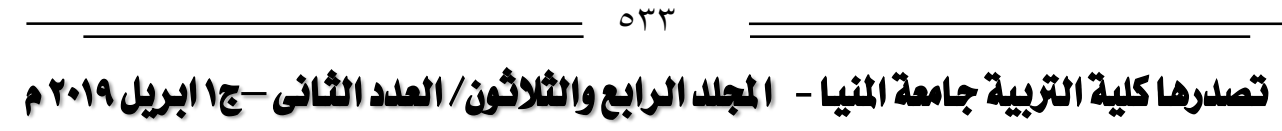



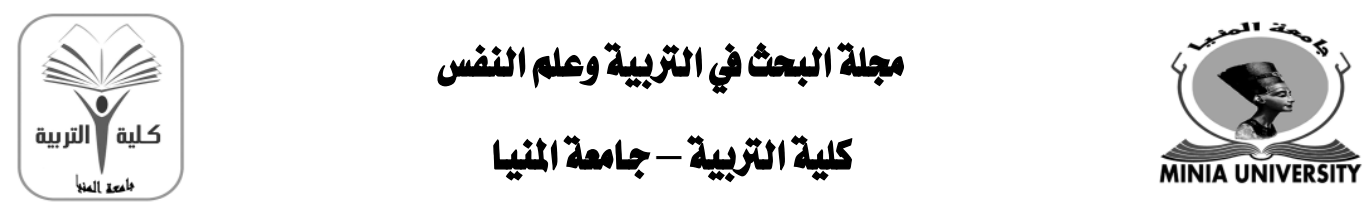

كلية مُعتمدة من الميئة القومية لضمان جودة التمليم

\section{Significance of the Study}

The adaptation of weblogs in the tertiary level in relation to the paradigm of academic writing through the present study is hopefully expected to:

- strengthen 21 st century students' digital literacy and empower them with the skills of producing academic papers concerning the content and the form together with a clear presentation of their writing identity.

- broaden the awareness of language teachers with the increasing influence of digital and online tools to allow their students to acquire new competencies for professional and personal development, unattainable in the traditional classroom. Moreover, they would be oriented with the basics of writing about academic research in English enabling them and their students as well to be better authors and academic writers.

- enable curriculum designers to cater for materials and activities that develop learners' effective authorial identity to be recognized within their own discipline. Additionally, they would be enabled to address both linguistic forms and functions in the design of academic writing curricula and thus help improve foreign language learners' academic writing competence.

- enlighten researchers' perspectives to advance work on writing, feedback, and identity to better support emerging researchers.

Delimitations of the study

The present study was delimited to the following elements:

1- The participants are fourth- year English majors, seniors, enrolled at the Faculty of Education, Minia University, in the second semester of the academic year 2017/2018.

2- On single class blog is the weblog format used in the present study.

3- Style conventions, tone conventions, packaging information, linking markers, textual meta-discourse markers and

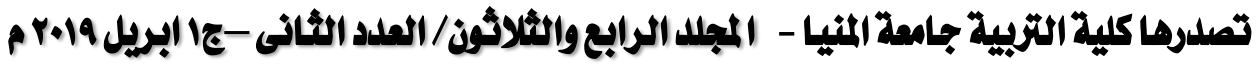

gamel_abd059@yahoo.com http://ms.minia.edu.eg/edu/journal.aspx 

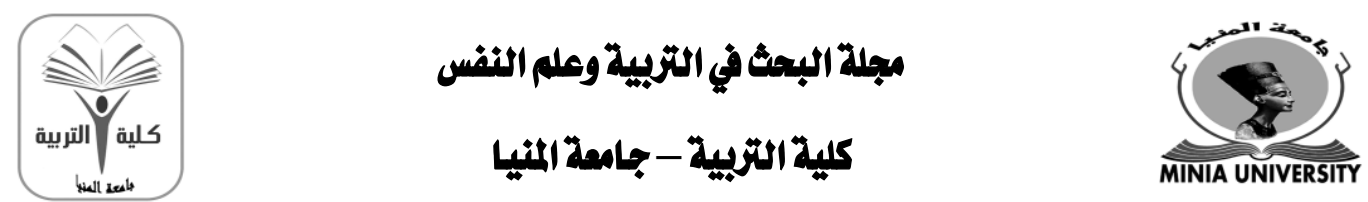

كلية مُعتمدة من الميئة القومية لضمان جودة التمليم

interpersonal meta-discourse markers are the aspects of academic writing that have been tackled in the present study.

4- Three rhetorical moves of Harris' (2006) five moves for promoting authorial identity through academic writing have only been incorporated at the present study. The three rhetorical moves used in this study are: coming to terms, forwarding and countering.

Definitions of terms

weblogs

- Zhang (2009, cited in Aljumah, 2012 :101) defined it as a webbased space for writing where all the writing and editing of information is managed through a web browser and is immediately and publicly available on the Internet.

- Aydin (2014: 244) defined it as a site or online journal published on the World Wide Web (WWW) for discussion or informational purposes in a reverse chronological order.

- Operationally, it is defined in the present study as a personal online space where an author, blogger, publishes a series of posts archived in reverse chronological order, with an option for readers to comment on these posts, and collects and shares resources.

Academic Writing

- Hyland (2002: 1092) defined academic writing as, any form of communication, an act of identity that not only conveys disciplinary content but also carries a presentation of the writer.

- Akkaya and Aydin (2018: 129) defined academic writing as the production of logically structured ideas with well-thought out and verified points through the consideration of different opinions.

- Operationally, the term is used in this study to refer to the process of producing any piece of written product that is clear, understandable and concise, and which is presented through following certain writing conventions ensuring coherence and cohesion among its subsections.

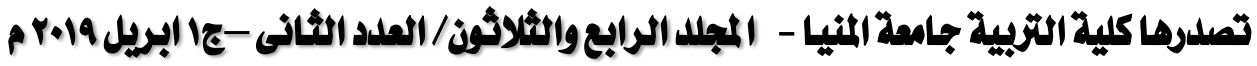

gamel_abdo59@yahoo.com

http://ms.minia.edu.eg/edu/journal.aspx 

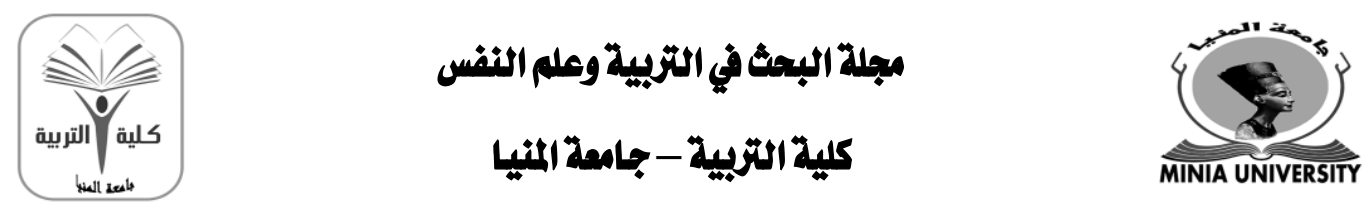

كلية مُعتمدة من الميئة القومية لضمان جودة التمليم

\section{Authorial Identity}

- Pittam, et. (2009:153) defined it as the sense a writer has as an author and the textual identity constructed in his/her writing.

- Hryniuk (2018: 623) defined it as the degree to which writers establish presence in their texts, relating to their opinions, beliefs and position.

- Operationally, it is defined in the present study as the textual representations writers construct in their writing articulating their Method position clearly, particularly in relation to other voices in the texts.

\section{Design of the study}

The present study utilized the quasi-experimental research design. The pre-post control group design (Hatch and Farhady, 1982) was used in designing and conducting the study. A treatment group and a non - treatment group were exposed to pre and post means of getting data. The treatment group only was instructed and trained using a program- oriented towards using weblogs while the non-treatment group did not receive such training.

Participants of the Study

The main sample of the study consisted of sixty (60) English majors enrolled in the fourth year at the Faculty of Education, Minia University in the academic year 2017/2018. They were randomly divided into two equal intact groups; treatment and non-treatment and were of the same age level and the same grade level. Homogeneity was established between participants in both groups at the entry level before the intervention as follows:

Age. The two groups of the study were matched on age as the age level of all the participants ranged from 21.5: 23 years old with nearly the same number in each group. Table (1) shows no significant difference between the participants in both groups as the $(t)$ value $(0.283)$ is not significant at 0.05 level.

Table (1)

Means, Standard Deviation and t-value of participants' age

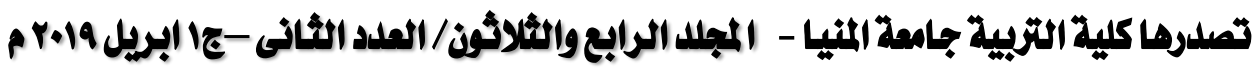

gamel_abdo59@yahoo.com

http://ms.minia.edu.eg/edu/journal.aspx 


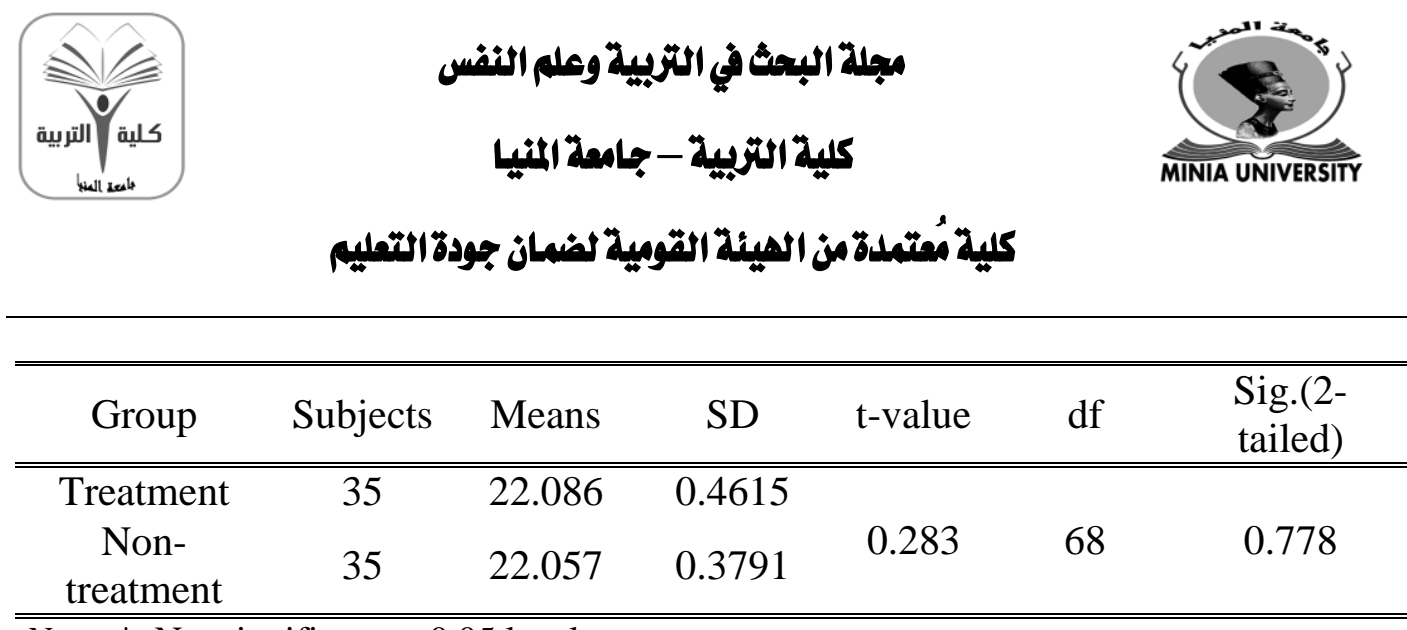

Note. *. Not significant at 0.05 level

Level of language proficiency. The two groups of the study were matched on their level of language proficiency. Table (2) shows no significant difference between the participants in both groups as the $(t)$ value $(0.700)$ is not significant at 0.05 level.

Table (2)

Means, Standard Deviation and t-value of participants' writing proficiency

\begin{tabular}{ccccccc}
\hline \hline Group & Subjects & Means & SD & t-value & df & $\begin{array}{c}\text { Sig.(2- } \\
\text { tailed) }\end{array}$ \\
\hline \hline $\begin{array}{c}\text { Treatment } \\
\begin{array}{c}\text { Non- } \\
\text { treatment }\end{array}\end{array}$ & 35 & 9.46 & 1.197 & & & \\
\hline Note. *. Not significant at 0.05 level & & & & & & \\
\hline
\end{tabular}

Linguistic background. All the participants studied English for 12 years (from primary (1) till the end of the secondary stage) at public schools in Minia Governorate. In addition to another 3 years at their university level till they became seniors.

Variables of the Study

The independent variable. The use of a weblog orientedprogram.

The dependent variables. They include the level of academic writing and the level of authorial identity. Instruments of the study

1- A needs- analysis survey of academic writing conventions

The academic writing conventions had been listed after reviewing the related literature and was administered to jury members to select the most important and relevant conventions to be included in the present program.

2- A questionnaire of academic writing skills.

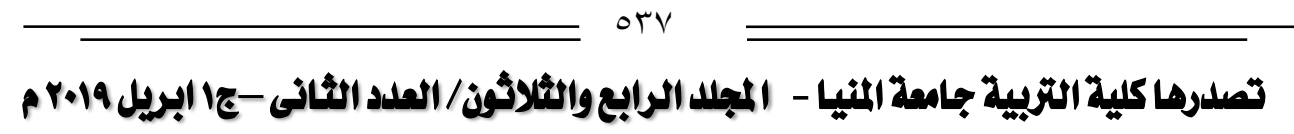

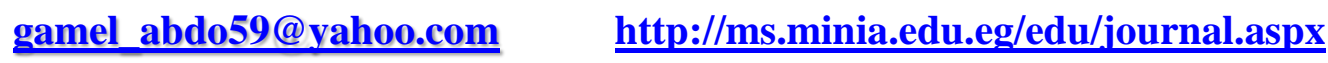



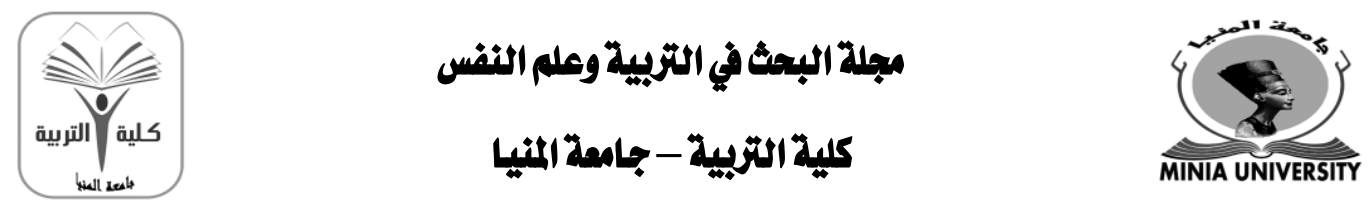

كلية مُعتمدة من الميئة القومية لضمان جودة التمليم

Purposes of the questionnaire. Identifying the beliefs that the EFL senior students hold as well as their background knowledge concerning their academic writing skills. It also helps in figuring out the students' coping skills used during facing problems in their writing assignments.

Construction of the questionnaire. a- Reviewing the literature related to the domain of academic writing. $b$ - Stating the objectives of the questionnaire. c- Designing a preliminary questionnaire. It consists of three variables with 10 multiplechoice items. d- Evaluating the preliminary form of the questionnaire by a jury of 5 TEFL experts.

Validity of the questionnaire. A jury of 5 TEFL experts approved the face validity of the questionnaire, its suitability and appropriacy for the study sample.

Administration of the questionnaire. The questionnaire was administered to EFL senior students to determine their beliefs, background knowledge as well as the coping strategies they demonstrate in relation to their academic writing tasks.

Results. Analyzing the data obtained revealed that the majority of the participants considered themselves as writers. However, most of them believed that they could not either express ideas in their own words or present themselves in their writing products. Concerning their background knowledge of academic writing, most of them assured their wide background knowledge of academic writing conventions. In relation to actual writing practices, the majority reported using quoting more than paraphrasing with almost no idea about the style of referencing used in academic English assignments. Regardless of receiving very limited constructive feedback, most of them assured their seek of help during performing writing assignments due to interference between their first language and English.

Table (3) presents the percentage of the participants' choice of the items of the questionnaire.

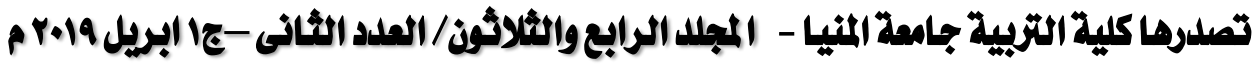

gamel_abdo59@yahoo.com

http://ms.minia.edu.eg/edu/journal.aspx 

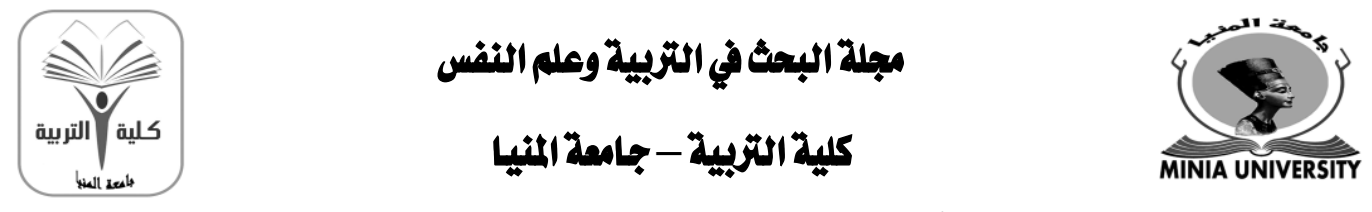

كلية مُعتمدة من الهيئة القومية لضمان جودة التمليم

Table (3)

Questionnaire Analysis

\begin{tabular}{|c|c|c|c|c|}
\hline The Variable & $\begin{array}{c}\text { Corresponding } \\
\text { number of } \\
\text { statements }\end{array}$ & $\begin{array}{r}\text { Variab } \\
\text { dis }\end{array}$ & $\begin{array}{l}\text { ponse } \\
\text { on }\end{array}$ & $\begin{array}{c}\text { Total number } \\
\text { (N) }\end{array}$ \\
\hline \multirow{6}{*}{ Personal believes } & \multirow[b]{2}{*}{1} & $\overline{\text { Often }}$ & $10 \%$ & \\
\hline & & Few & $90 \%$ & \\
\hline & \multirow{2}{*}{2} & Often & $10 \%$ & \\
\hline & & Few & $90 \%$ & \\
\hline & \multirow{2}{*}{3} & Often & $10 \%$ & \\
\hline & & Few & $90 \%$ & \\
\hline \multirow{8}{*}{$\begin{array}{l}\text { Background } \\
\text { knowledge }\end{array}$} & \multirow{2}{*}{4} & Often & $10 \%$ & \\
\hline & & Few & $90 \%$ & \\
\hline & \multirow{2}{*}{5} & Few & $10 \%$ & \\
\hline & & Rare & $90 \%$ & \\
\hline & \multirow{2}{*}{6} & Often & $90 \%$ & 30 \\
\hline & & Few & $10 \%$ & \\
\hline & \multirow{2}{*}{7} & Often & $10 \%$ & \\
\hline & & Few & $90 \%$ & \\
\hline \multirow{6}{*}{ Coping strategies } & \multirow{2}{*}{8} & Often & $90 \%$ & \\
\hline & & Few & $10 \%$ & \\
\hline & \multirow{2}{*}{9} & Often & $10 \%$ & \\
\hline & & Few & $90 \%$ & \\
\hline & \multirow{2}{*}{10} & Often & $90 \%$ & \\
\hline & & Few & $10 \%$ & \\
\hline
\end{tabular}

\section{3- A Test of academic writing}

Purpose of the test. A test of academic writing was designed by the researcher for EFL seniors enrolled at the Faculty of Education to assess the knowledge and skills of their academic writing, ensure equality of the participants in the treatment and non-treatment groups through piloting and measure the degree of

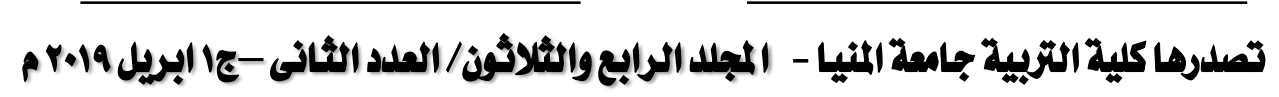

gamel_abdo59@yahoo.com http://ms.minia.edu.eg/edu/journal.aspx 

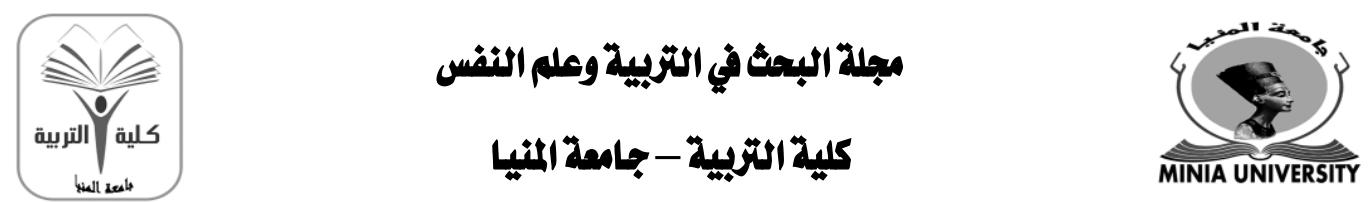

كلية مُعتمدة من الميئة القومية لشمان جودة التمليم

improvement of the participants in both groups on their academic writing after finishing the course.

Construction of the test. It consists of two sections: knowledge and use. The knowledge section includes 28 items and the use section includes 32 items with the total number of 60 items for the whole test. It is constructed according to a table of specification on the basis of the academic writing topics of the suggested program. Items are of the multiple-choice type. One point is given for each test item. The maximum score of this test is 60 .

Instructions of the test. They are written in English. They are brief and easy to understand. They include information about the purpose of the test, the way of recording the answers and the time allowed to complete the test.

Piloting the test. Piloting the test was done with a group of thirty (30) male and female English seniors enrolled at the Faculty of Education, Minia University in the academic year 2017/2018. Those participants were excluded later on from the intervention. Time taken by each student was recorded, divided by the whole number of the participants who took the test which was found to be 90 minutes. Thus, the testing time was 90 minutes.

Validity of the test.

1- The face validity of the test. It was determined by submitting it to a jury of 5 TEFL experts to judge its validity according to the following criteria: linguistic stating of items, how far the items measure the objectives of the program and suitability of items for the participants. The suggestions and recommendations of the jury members were taken into consideration and the test was revised to reach its final form.

2- Pearson correlation formula. It was used to determine the internal consistency of the test. 30 EFL seniors enrolled in the Faculty of Education were selected randomly to take the test. The internal consistency of the individual items of both section one (knowledge) and two (use) was calculated as shown in table

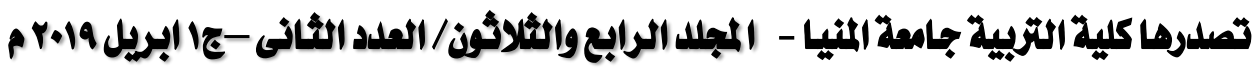

gamel_abdo59@yahoo.com

http://ms.minia.edu.eg/edu/journal.aspx 

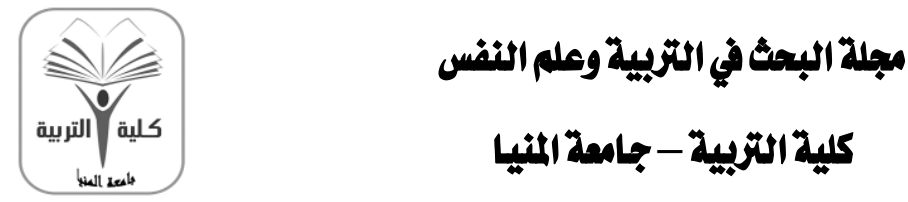

كايلة التزبية - جامعة المنيا

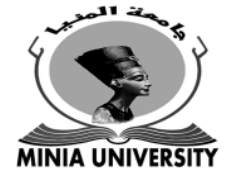

كلية مُقتملةمن الميئة القومية لضمان جودة التمليم

(4). The correlation between the two sections of the test and the total test was determined as shown in table (5). The values of the correlation coefficient, ranged from $(0.364: 0.763)$, are considered acceptable.

Table (4)

The Internal Consistency of the Test of Academic writing

\begin{tabular}{cccccc}
\hline \hline Item & $\begin{array}{c}\text { Internal } \\
\text { consistency }\end{array}$ & Item & $\begin{array}{c}\text { Internal } \\
\text { consistency }\end{array}$ & Item & $\begin{array}{c}\text { Internal } \\
\text { consistency }\end{array}$ \\
\hline 1 & $.560^{* *}$ & 21 & $.557^{* *}$ & 41 & $.578^{* *}$ \\
2 & $.419^{*}$ & 22 & $.476^{* *}$ & 42 & $.528^{* *}$ \\
3 & $.476^{* *}$ & 23 & $.547^{* *}$ & 43 & $.514^{* *}$ \\
4 & $.645^{* *}$ & 24 & $.705^{* *}$ & 44 & $.504^{* *}$ \\
5 & $.560^{* *}$ & 25 & $.499^{* *}$ & 45 & $.508^{* *}$ \\
6 & $.430^{*}$ & 26 & $.440^{*}$ & 46 & $.561 * *$ \\
7 & $.624^{* *}$ & 27 & $.538^{* *}$ & 47 & $.495^{* *}$ \\
8 & $.405^{*}$ & 28 & $.390^{*}$ & 48 & $.457^{*}$ \\
9 & $.453^{*}$ & 29 & $.398^{*}$ & 49 & $.638^{* *}$ \\
10 & $.492^{* *}$ & 30 & $.418^{*}$ & 50 & $.462^{*}$ \\
11 & $.626^{* *}$ & 31 & $.457^{*}$ & 51 & $.548^{* *}$ \\
12 & $.364^{*}$ & 32 & $.418^{*}$ & 52 & $.391^{*}$ \\
13 & $.763^{* *}$ & 33 & $.400^{*}$ & 53 & $.418^{*}$ \\
14 & $.724 * *$ & 34 & $.468^{* *}$ & 54 & $.428^{*}$ \\
15 & $.822^{* *}$ & 35 & $.580^{* *}$ & 55 & $.418^{*}$ \\
16 & $.523^{* *}$ & 36 & $.518^{* *}$ & 56 & $.408^{*}$ \\
17 & $.763^{* *}$ & 37 & $.488^{* *}$ & 57 & $.368^{*}$ \\
18 & $.616^{* *}$ & 38 & $.468^{* *}$ & 58 & $.447^{*}$ \\
19 & $.704^{* *}$ & 39 & $.688^{* *}$ & 59 & $.508^{* *}$ \\
20 & $.647^{* *}$ & 40 & $.588^{* *}$ & 60 & $.428^{*}$ \\
\hline \hline
\end{tabular}

Note. **. Correlation is significant at the 0.01 level (2-tailed).

Note. *. Correlation is significant at the 0.05 level (2-tailed).

Table (5)

The correlation of the total of each section with the total of the two sections of the test

\begin{tabular}{lc}
\hline \hline \multicolumn{1}{c}{ Sections } & Internal consistency \\
\hline \hline The total of section one (knowledge) & $.832^{* *}$ \\
The total of section two (use) & $.825^{* *}$ \\
\hline \hline
\end{tabular}

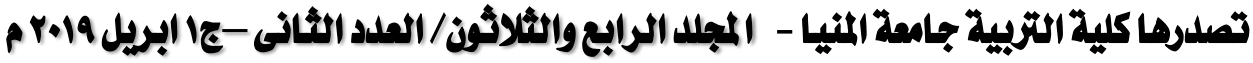

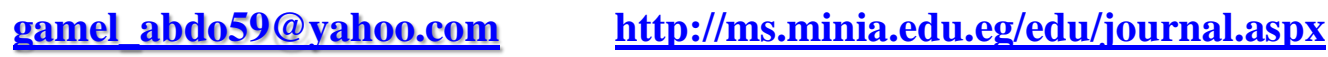



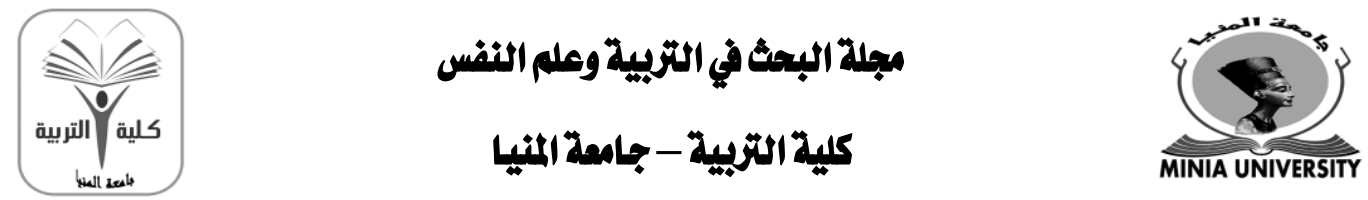

كلية مُتملةةمن الميئة القومية لضمان جودة التمليي

Note. **. Correlation is significant at the 0.01 level (2-tailed).

Reliability of the test. Establishing the reliability of the test was done during piloting. The same piloting sample (30 EFL senior students) were randomly selected to take the test. The reliability coefficient of the test was determined using:

1- Alpha Cronbach (a) coefficient. It is (0.926). It is considered acceptable as shown in table (6).

Table (6)

The Cronbach Alpha's Reliability coefficient of the test

\begin{tabular}{cccccc}
\hline $\begin{array}{c}\text { The test } \\
\text { sections }\end{array}$ & Means & Variance & $\begin{array}{c}\text { Standard } \\
\text { Deviation }\end{array}$ & $\begin{array}{c}\text { No. of } \\
\text { items }\end{array}$ & Alpha \\
\hline $\begin{array}{c}\text { Section 1 } \\
\text { (Knowledge) } \\
\begin{array}{c}\text { Section2 } \\
\text { (Use) }\end{array}\end{array}$ & 9.90 & 57.059 & 7.554 & 28 & 0.919 \\
Total & 10.90 & 54.921 & 7.411 & 32 & 0.894 \\
\hline \hline
\end{tabular}

Note. *. Alpha is significant at the 0.05 level (2-tailed).

2- Test- retest method. It occurred with nearly two weeks intervals between the first and the second scorings. It was administered to the same randomly chosen sample (30 EFL senior students) for calculating reliability coefficient of the test. The total reliability coefficient of the test is $(\mathbf{0 . 9 9 3})$ which is considered acceptable as shown in table (7).

Table (7)

Test-Retest Reliability Coefficient of the Test

\begin{tabular}{cccccccc}
\hline \hline Sections & Means & SD & Means & SD & t-value & $\begin{array}{c}\text { Sig. } \\
\text { (2-tailed) }\end{array}$ & Correlation \\
\hline Knowledge & 9.90 & 7.554 & 9.77 & 7.709 & 0.849 & 0.403 & $.994^{* *}$ \\
Use & 10.90 & 7.411 & 11.20 & 7.462 & -1.248 & 0.222 & $.984^{* *}$ \\
Total & 20.80 & 12.402 & 20.97 & 12.963 & -0.571 & 0.573 & $.993^{* *}$ \\
\hline \hline
\end{tabular}

Note. **. Correlation is significant at the 0.01 level (2-tailed).

Cohen et al. (2007:530) point out that the reliability coefficients are considered reliable if they range from 0.50 to 0.90 . Thus, the reliability coefficients of the test are considered within the acceptable range.

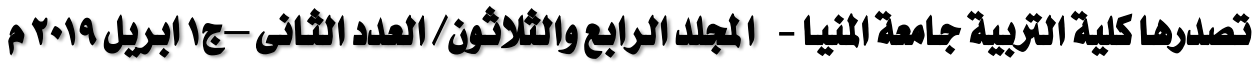

gamel_abd059@yahoo.com http://ms.minia.edu.eg/edu/journal.aspx 

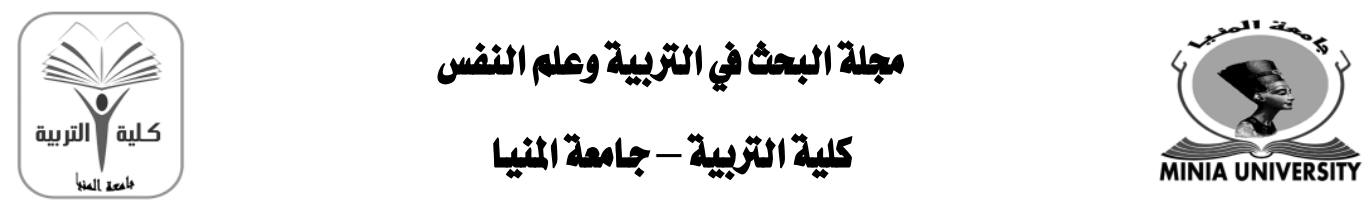

كلية مُعتمدة من الميئة القومية لشمان جودة التمليم

Item analysis. It evaluates the effectiveness of the items and of the test as a whole.

Index of difficulty. Analysis of the responses to individual items was calculated to determine item difficulty for the test. The difficulty of the items is understood as the proportion of the persons who answer a test item correctly. The index of difficulty of this test ranged from 43.33 to 70 .

Item discrimination. It is the ability of the item to differentiate more knowledgeable students from the less knowledgeable. To calculate knowledge, the top scoring students are separated from the bottom scoring students and then their response patterns would be compared. After calculating the discriminating power of the items, it was found that the items had a positive discriminating power. None of the items had a zerodiscriminating power. The power of discrimination of the test ranged from 0.33 to 0.60 .

\section{4-A scale of authorial identity}

Purpose of the scale. A scale of authorial identity was designed by the researcher for English seniors to identify the different dimensions of their authorial identity and measure the degree of improvement of the participants in both groups on the level of their authorial identity after finishing the course.

Construction of the scale. It is constructed on the basis of a three-point Likert-type scale. The most important dimensions of authorial identity are classified and represented in the scale through a group of five dimensions, each followed by a group of statements that are developed for measuring participants' authorial identity after being involved in a weblog-oriented program with the total number of 38 statements. 35 statements are classified as being positive while three statements (no. 4, 25, 34) are reverse coded. Each statement has three response categories rating as follows: disagree, undecided and agree. Responses are given scores (weights) according to the scale

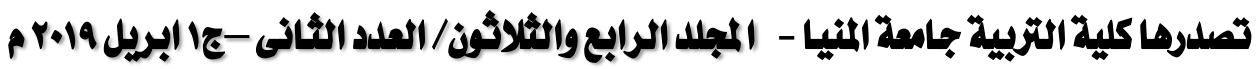

gamel_abdo59@yahoo.com

http://ms.minia.edu.eg/edu/journal.aspx 


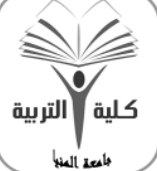

مجلة البعث في التزبية وملم النفس

كلية التربية - جامعة المنيا

MINIA UNIVERSITY

كلية مُعتملة من الميئة القومية لضمان جودة التمعيم

response categories as follows: disagree (1), undecided (2) and agree (3). Maximum score on the scale is 108. This is shown in table (8).

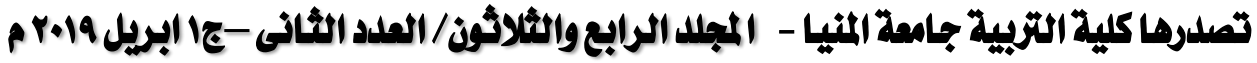

gamel_abd059@yahoo.com http://ms.minia.edu.eg/edu/journal.aspx 

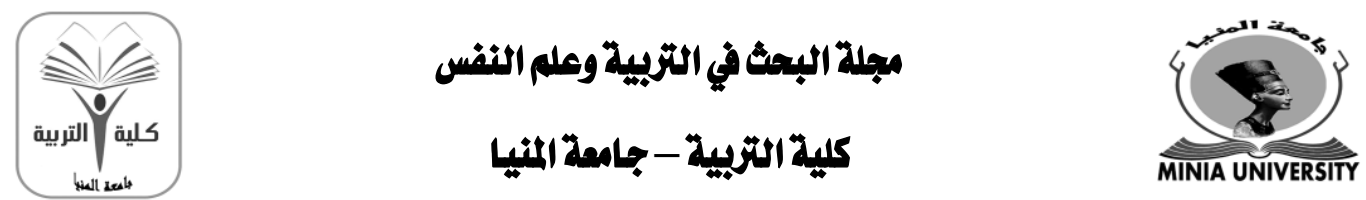

كلية مُتملةة من الميئة القومية لضمان جودة التمليي

Table (8)

The Dimensions of The Authorial Identity Scale

\begin{tabular}{ccc}
\hline \hline No. & Scale dimensions & No. of items \\
\hline \hline 1 & Beliefs & 10 \\
2 & Discourse features & 9 \\
3 & Obstacles & 7 \\
4 & Rhetorical consciousness- & 5 \\
5 & raising & 7 \\
Total number of items & Social constructs & \\
Total score & 38 & \\
\hline \hline
\end{tabular}

Instructions of the scale. They are written in English. They are easy to understand. They include information about the purpose of the scale, its dimensions, the distribution of the scores on the points of the scale and the way of recording the answer.

Piloting the scale. Piloting the scale was done with a group of thirty (30) male and female EFL senior students enrolled at the Faculty of Education, Minia University in the academic year 2017/2018. Those participants were excluded later on from the intervention. Time taken by each participant was recorded, divided by the whole number of participants who took the scale and was found to be $\mathbf{4 5}$ minutes. Thus, the allotted time for using the scale was 46 minutes.

Validity of the scale.

1- The face validity of the scale. It was determined by submitting it to a jury of 5 TEFL experts to judge its validity according to the following criteria: linguistic stating of statements, relatedness of the statements to the dimensions of authorial identity and suitability of the statements to the subjects. The suggestions and recommendations of the jury members were taken into consideration and the scale was revised to reach its final form.

2- Pearson correlation. It was used to determine the internal consistency of the inventory. The same piloting sample (30 EFL

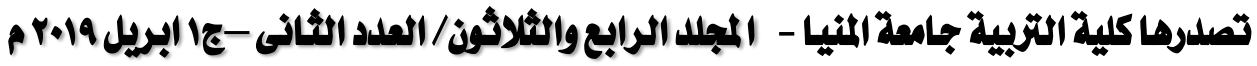

gamel_abdo59@yahoo.com

http://ms.minia.edu.eg/edu/journal.aspx 


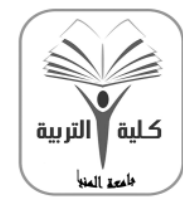

مجلة البعث في التربية وملم النفس

كلية التربية - جامعة المنيا

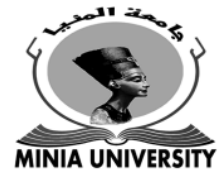

كلية مُعتمدة من الميئة القومية لضمان جودة التمليم

senior students) took the scale. The internal consistency of each statement was calculated. The internal consistency of the individual statements of the dimensions of the scale was calculated as shown in table (9). The correlation between the five dimensions of the scale and the total scale was determined as shown in table (10). The values of the correlation coefficient, ranged from (0.470: 0.985$)$, are considered acceptable.

Table (9)

The Internal Consistency of the scale of authorial identity

\begin{tabular}{|c|c|c|c|c|c|}
\hline Item no. & $\begin{array}{c}\text { Internal } \\
\text { consistency }\end{array}$ & Item no. & $\begin{array}{l}\text { Internal } \\
\text { consistency }\end{array}$ & Item no. & $\begin{array}{c}\text { Internal } \\
\text { consistency }\end{array}$ \\
\hline A1 & $.921 * *$ & B4 & $.505 * *$ & D1 & $.735 * *$ \\
\hline A2 & $.870 * *$ & B5 & $.888 * *$ & D2 & $.918^{* *}$ \\
\hline A3 & $.510 * *$ & B6 & $.666 * *$ & D3 & $.820 * *$ \\
\hline A4 & $.904 * *$ & B7 & $.844 * *$ & D4 & $.481 * *$ \\
\hline A5 & $.822 * *$ & B8 & $.628 * *$ & D5 & $.533 * *$ \\
\hline A6 & $.698 * *$ & B9 & $.470 * *$ & E1 & $.785^{* *}$ \\
\hline A7 & $.985 * *$ & $\mathrm{C} 1$ & $.800 * *$ & E2 & $.570 * *$ \\
\hline A8 & $.740 * *$ & $\mathrm{C} 2$ & $.855^{* * *}$ & E3 & $.740 * *$ \\
\hline A9 & $.560 * *$ & C3 & $.837 * *$ & E4 & $.754 * *$ \\
\hline A10 & $.785^{* *}$ & $\mathrm{C} 4$ & $.736 * *$ & E5 & $.869 * *$ \\
\hline B1 & $.523 * *$ & $\mathrm{C} 5$ & $.681 * *$ & E6 & $.669 * *$ \\
\hline B2 & $.845^{* *}$ & C6 & $.608 * *$ & E7 & $.520 * *$ \\
\hline B3 & $.684^{* *}$ & C7 & $.505^{* *}$ & - & - \\
\hline \multicolumn{6}{|c|}{$\begin{array}{l}\text { Note. **. Correlation is significant at the } 0.01 \text { level (2-tailed). } \\
\text { Table (10) } \\
\text { The Correlation Between Each Dimension and The Total Scale }\end{array}$} \\
\hline \multicolumn{3}{|c|}{ Dimensions } & \multicolumn{3}{|c|}{ Internal consistency } \\
\hline \multicolumn{3}{|c|}{ Beliefs } & \multicolumn{3}{|c|}{$7.761 * *$} \\
\hline \multicolumn{3}{|c|}{ Discourse features } & \multicolumn{3}{|c|}{$.804 * *$} \\
\hline \multicolumn{3}{|c|}{ Obstacles } & \multicolumn{3}{|c|}{$.603^{* *}$} \\
\hline \multirow{2}{*}{\multicolumn{3}{|c|}{ Rhetorical consciousness-raising }} & \multicolumn{3}{|c|}{$.418^{*}$} \\
\hline & & & \multicolumn{3}{|c|}{$.529 * *$} \\
\hline
\end{tabular}

Note. ${ }^{* *}$. Correlation is significant at the 0.01 level (2-tailed).

Note. *. Correlation is significant at the 0.05 level (2-tailed).

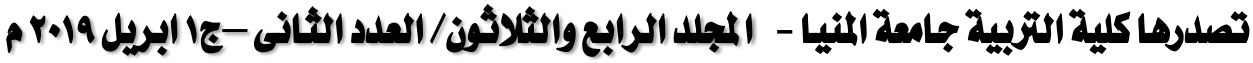

gamel_abdo59@yahoo.com http://ms.minia.edu.eg/edu/journal.aspx 

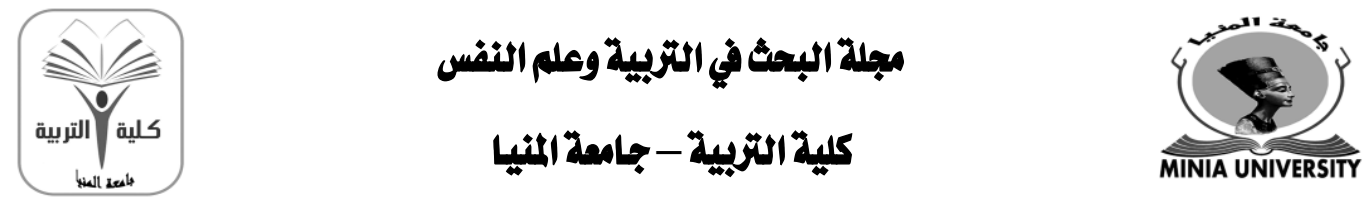

كلية مُعتمدة من الميئة القومية لضمان جودة التمليم

Reliability of the scale. Establishing the reliability of the scale was done during piloting. The same piloting sample (30 EFL senior students) took the scale. The reliability coefficient of the scale was determined using:

1- Alpha Cronbach ( $\alpha$ ) coefficient. It is $(0.897)$. It is considered acceptable as shown in table (11).

Table (11)

The Cronbach Alpha's Reliability coefficient of the scale

\begin{tabular}{|c|c|c|c|c|c|}
\hline Domains & Means & Variance & $\begin{array}{l}\text { Standard } \\
\text { Deviation }\end{array}$ & $\begin{array}{l}\text { No. of } \\
\text { items }\end{array}$ & Alpha \\
\hline Beliefs & 11.37 & 7.482 & 2.735 & 10 & 0.934 \\
\hline $\begin{array}{l}\text { Discourse } \\
\text { features }\end{array}$ & 14.07 & 4.478 & 2.116 & 9 & 0.848 \\
\hline Obstacles & 15.53 & 5.361 & 2.315 & 7 & 0.843 \\
\hline $\begin{array}{l}\text { Rhetorical } \\
\text { consciousness- } \\
\text { raising }\end{array}$ & 7.87 & 2.809 & 1.676 & 5 & 0.727 \\
\hline $\begin{array}{c}\text { Social } \\
\text { constructs }\end{array}$ & 10.13 & 3.292 & 1.814 & 7 & 0.823 \\
\hline $\begin{array}{c}\text { Total of } \\
\text { dimensions } \\
\end{array}$ & 58.97 & 46.723 & 6.835 & 38 & 0.897 \\
\hline
\end{tabular}

Note. *. Alpha is significant at the 0.05 level (2-tailed).

2- Test- retest method. It occurred with nearly two weeks intervals between the first and the second scorings. It was administered to the same randomly chosen sample (30 EFL senior students) for calculating reliability coefficient of the scale. The total reliability coefficient of the scale is $(0.974)$ which is considered acceptable as shown in table (12).

Table (12)

Test-Retest Reliability Coefficient of the scale of authorial identity

\begin{tabular}{|c|c|c|c|c|c|c|c|}
\hline Dimensions & Means & SD & Means & SD & t-value & $\begin{array}{c}\text { Sig. } \\
(2- \\
\text { tailed) }\end{array}$ & Correlation \\
\hline Beliefs & 11.37 & 2.735 & 111.70 & 2.855 & -1.624 & 0.115 & $.920 * *$ \\
\hline $\begin{array}{l}\text { Discourse } \\
\text { features }\end{array}$ & 14.07 & 2.116 & 14.27 & 2.196 & -1.649 & 0.110 & $.953 * *$ \\
\hline
\end{tabular}

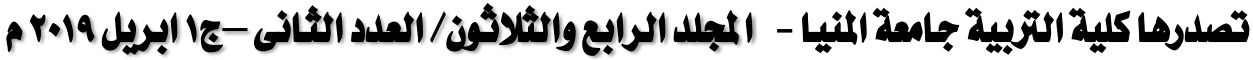

gamel_abdo59@yahoo.com http://ms.minia.edu.eg/edu/journal.aspx 


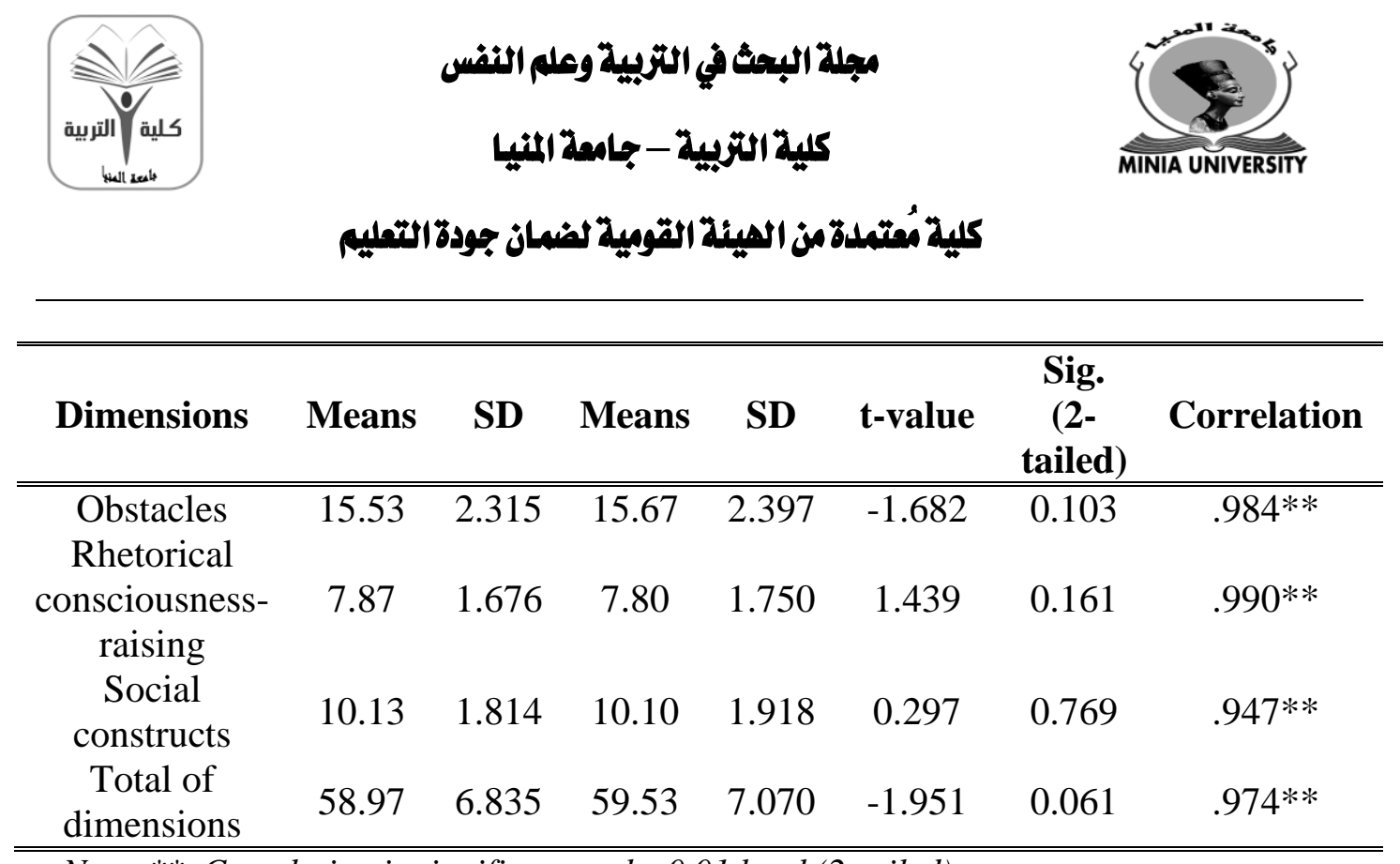

Note. **. Correlation is significant at the 0.01 level (2-tailed).

Cohen et al. (2007:530) point out that the reliability coefficients are considered reliable if they range from 0.50 to 0.90 . Thus, the reliability coefficients of the scale are considered within the acceptable range.

The material

a- The material (the training program) consists of 4 units divided into two parts: creating a personal profile (unit one) and rhetorical moves and creating identities (unit two, three and four).

b- The construction of the training program has gone through the following steps: reviewing the literature related to the domain of academic writing and authorial identity, stating the general and the specific objectives of each lesson, preparing the content, submitting the program to 5 TEFL jury members to be judged according to the following criteria; statement of items, academic verification of the content, appropriateness of the method and the techniques used for the content and the participants of the study and applicability of the program.

Instructional design of the study

1- A questionnaire of academic writing skills was designed and applied by the researcher to be informed about the beliefs that EFL senior students hold, their background knowledge

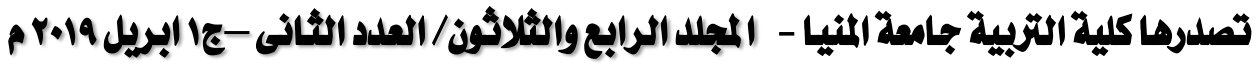

gamel_abdo59@yahoo.com http://ms.minia.edu.eg/edu/journal.aspx 

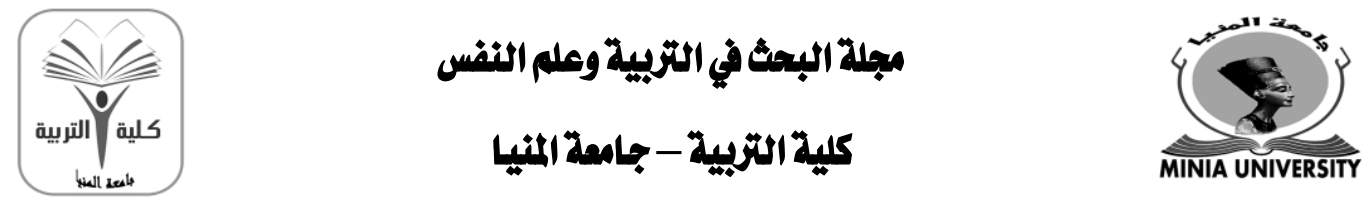

كلية مُعتمدة من الميئة القومية لضمان جودة التمليم

concerning academic writing and their coping strategies during involvement in writing assignments.

2- Pre-testing the participants of both the treatment and nontreatment groups, $(\mathrm{N}=60)$, using the test of academic writing and the scale of authorial identity before the intervention to ensure their homogeneity at the entry level.

3- The treatment intervention. The intervention of the treatment group has gone through the following stages:

a- Setting up a Blog Site. The researcher used a free blogging website (wordpress.com) to explain how to create a blog. Students were also given a video manual on how to create and post on a blog.

- A single website collaborative format (one class blog) was the one used in this study with the instructor as blog host and students as contributing authors.

- With this single blog, instead of individual blogs, participants did not have to look for others' blogs: all the current posts were on one webpage, and participants could click into the comments section with ease. All the participants could add as many postings as they liked while all postings would be chronologically listed in reverse order in the blog.

- It provided a forum for student writing. Their participation in the conversation was easier for students as the complete conversation literally would be more visible. Consequently, the total workload for participants and instructor alike were reduced.

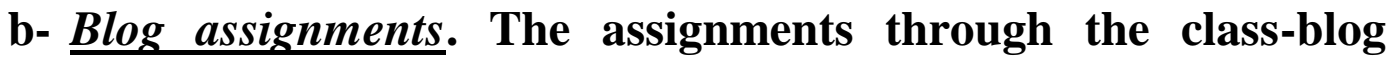
enabled the participants to:

- create their personal profile through some writing assigned posts (e.g. sketch your points of strength and weakness in your writing performance) to be shared on the group blog.

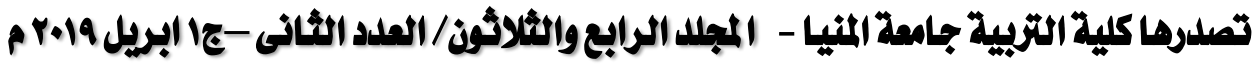

gamel_abdo59@yahoo.com

http://ms.minia.edu.eg/edu/journal.aspx 


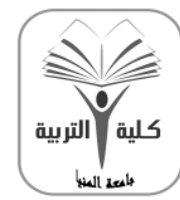

مجلة البعث في التربية وملم النفس

كلية التربية - جامعة المنيا

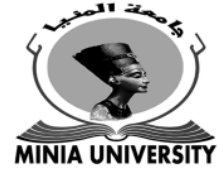

كلية مُعتملة من الميئة القومية لضمان جودة التمعيم

- engage in synchronous and asynchronous online discussions, and evaluative peer feedback. They have been able to post messages, discussions, and upload relevant multimedia illustrations and images,

- reflect on their personal posts and comment on their peers' posts, and

- practice selecting ideas, evaluating, concluding, and reporting.

c- The academic discourse of incorporating outside voices into participants' own writing. The rhetorical moves suggested by Harris (2006); coming to terms, forwarding and countering, for nurturing writers' authorial identities through academic writing assignments were adapted as follows:

- Coming to terms. In this stage, the participants were asked to enhance their writing skills through using paraphrasing, quotion, and summary together with using proper citation methods to avoid plagiarism.

- Forwarding. Here the participants were instructed to use academic texts to forward ideas, or evidence, in agreement with their arguments. They were required to refer to the source(s)they had read to be able to support their ideas and add value to their writing on the assigned topic. They were also instructed to reflect on the way they managed to distinguish their own voice among the other participating voices.

- Countering. Finally, they were asked to counter arguments and trace the limitations of academic arguments. The guidelines presented for each assignment asked participants to move away from depending on quotations and to focus instead on using their own authorial voice. They were allowed to incorporate external sources, and creatively borrow or extend the ideas and arguments of other authors while maintaining control over their own writing.

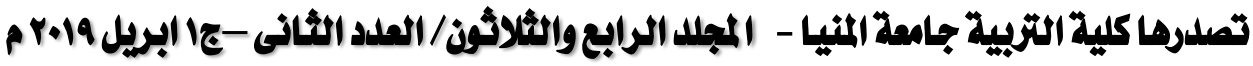



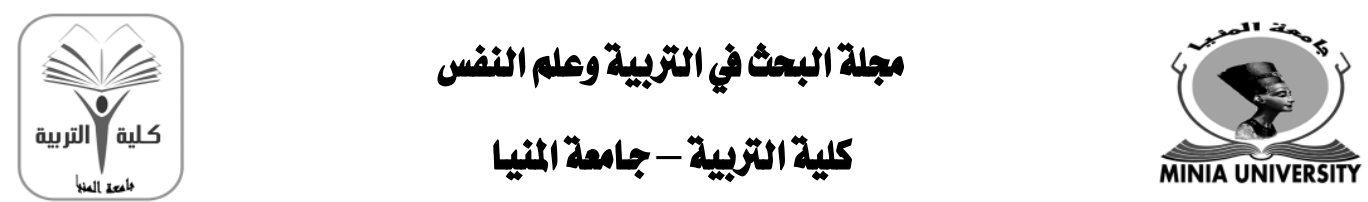

كلية مُعتمدة من الميئة القومية لشمان جودة التمليم

d- The writing tasks through the blog. The tasks used enabled the participants to progress gradually from tasks of knowledgetelling (e.g. introduce yourself to your community) in which they write to prove their understanding of existing knowledge, to more complex tasks of knowledge-transforming (e.g. state the main ideas presented in the assigned reading article in your own words) in which they actively construct new knowledge.

- The participants were asked to summarize, paraphrase and use direct quotations, and to incorporate the text into their own writing. They were asked to spot on the points of strength, gaps and limitations of the assigned reading materials, to consider new search space for their own writings. Hence, focusing on use rather than corrections and on the participants' ability to write while articulating a clear authorial voice.

- Since the quality of reflection is valued more than the length of the entries, there was no set word count.

4- The control treatment. Participants in the non-treatment group received instruction on the course of Writing using the regular way with no weblog intervention. The conventions of academic writing were tackled according to their appearance of the assigned topics with no predefined systematic order for their presentation. The dimension of authorial identity was not tackled directly and no special training was devoted for its promotion.

5- Post-testing the participants of both the treatment and nontreatment groups, $(\mathrm{N}=60)$, using the test of academic writing and the scale of authorial identity after the intervention to compare the results with the pre-testing results.

The instructor. The researcher taught the treatment group only using the weblog- oriented program by herself while the nontreatment group was instructed by another lecturer from the Faculty of Arts using the regular procedures according to the rules of the institution.

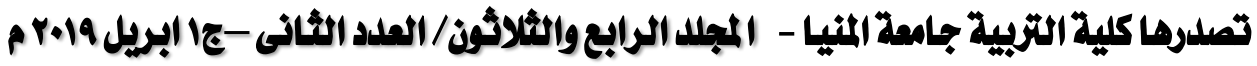

gamel_abdo59@yahoo.com

http://ms.minia.edu.eg/edu/journal.aspx 

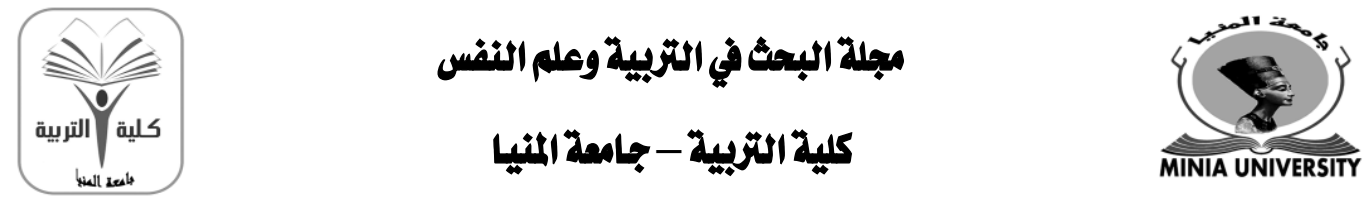

كلية مُتملةةمن الميئة القومية لضمان جودةالتمليي

The researcher served as a facilitator to guide the participants as they engaged on the blog project. The instructor's tasks mainly included setting up a group blog, discussing with the participants the difficulties they encountered in the blogging process, and providing suggestions to solve the problems.

Rather than using static examples from writing textbooks, the researcher used authentic materials that participants found in their own reading, thus allowing meaningful and relevant textual analysis.

The researcher had to monitor participants' interaction and provide timely intervention. She had to take part in participants' discussion and respond to questions online or in class to help keep the interactive dialogues on target and meaningful.

Findings

Hypothesis 1

The first hypothesis of the study predicted that there was a statistically significant difference (favoring the treatment group) between mean scores obtained by the participants of the treatment and the non-treatment groups on the post- performance of the test of academic writing. Statistical analysis of the obtained data showed that the treatment group achieved a higher degree of improvement than the non-treatment group on the test of academic writing as $t$-value (18.528) is significant at $(0.05)$ level and beyond. Thus, the first hypothesis is confirmed. Table (13) below shows the data obtained to test this hypothesis.

Table no. (13)

Means, Standard deviation, mean difference, $t$ value, $\eta 2$ and effect size on the post-performance of both the treatment and nontreatment groups of the test of academic writing

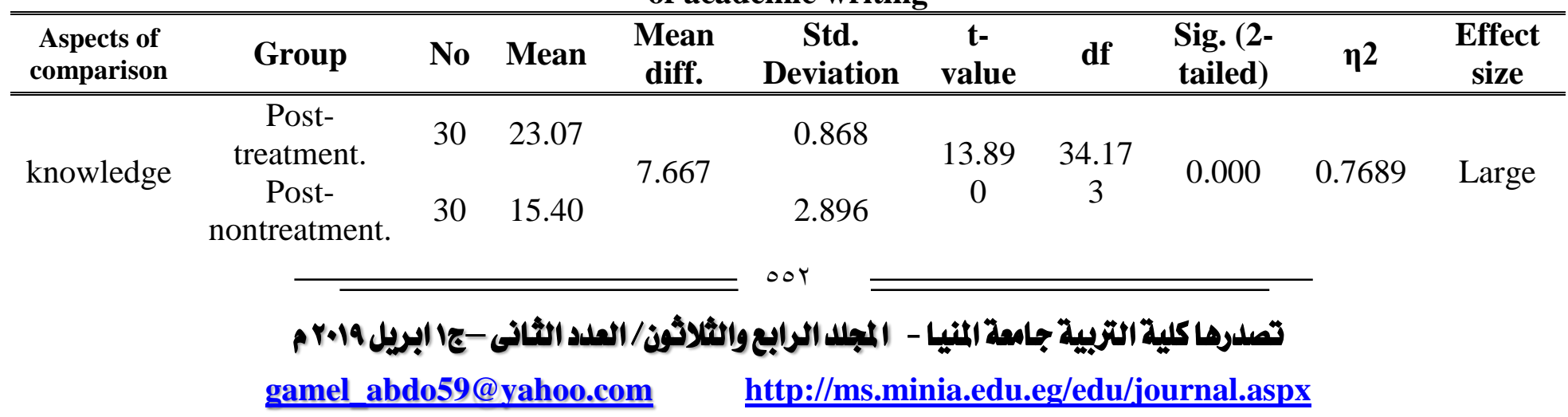




\begin{tabular}{|c|c|c|c|c|c|c|c|c|c|c|}
\hline \multicolumn{11}{|c|}{ كليلة مُقتملةمن الميئل القومية لضمان جودة التمليم } \\
\hline $\begin{array}{l}\text { Aspects of } \\
\text { comparison }\end{array}$ & Group & No & Mean & $\begin{array}{l}\text { Mean } \\
\text { diff. }\end{array}$ & $\begin{array}{c}\text { Std. } \\
\text { Deviation }\end{array}$ & $\begin{array}{c}\text { t- } \\
\text { value }\end{array}$ & df & $\begin{array}{l}\text { Sig. (2- } \\
\text { tailed) }\end{array}$ & $\eta 2$ & $\begin{array}{c}\text { Effect } \\
\text { size }\end{array}$ \\
\hline Use & $\begin{array}{c}\text { Post- } \\
\text { treatment. } \\
\text { Post- } \\
\text { nontreatment }\end{array}$ & $\begin{array}{l}30 \\
30\end{array}$ & $\begin{array}{l}24.53 \\
18.70\end{array}$ & 5.833 & $\begin{array}{l}0.681 \\
2.409\end{array}$ & $\begin{array}{c}12.76 \\
2\end{array}$ & $\begin{array}{c}33.61 \\
1\end{array}$ & 0.000 & 0.7374 & Large \\
\hline $\begin{array}{l}\text { Total of } \\
\text { the two } \\
\text { sections }\end{array}$ & $\begin{array}{l}\text { Post- } \\
\text { treatment. } \\
\text { Post- } \\
\text { nontreatment. }\end{array}$ & 30 & $\begin{array}{l}47.60 \\
34.10\end{array}$ & 13.500 & $\begin{array}{l}1.329 \\
3.763\end{array}$ & $\begin{array}{c}18.52 \\
8\end{array}$ & $\begin{array}{c}36.12 \\
0\end{array}$ & 0.000 & 0.8555 & Large \\
\hline
\end{tabular}

Note. *. significant at the 0.05 level (2-tailed)

To ensure the effectiveness of the weblog- oriented program in improving participants' academic writing, eta-squared formula statistics ( $\eta 2)$ was used. Cohen et al. (2007:522) pointed out that when eta-squared value $=0.01$, the effect is considered weak, when it $=0.06$, the effect is considered medium and when it $=0.14$ the effect is large. As shown in table (13) eta-squared value( $\eta 2)$ equals (0.8555) which is considered large. Thus, the weblogoriented program is considered with high effect in improving EFL senior students' academic writing.

Additionally, the comparison of the values obtained by the participants of both the treatment and non-treatment groups in the pre-post performance on the test of academic writing revealed that the treatment group outperformed the non-treatment group as t-value (24.823) is significant at 0.05 level and beyond. Etasquared value $(\eta 2)$ equals $(0.9551)$ which is considered large. This is shown in table (14).

Table (14)

Means, Standard Deviation, $t$ value, $\eta 2$ and effect size between mean scores of the treatment and the non-treatment groups on the Pre-Post performance of the test of academic writing. $N=30$

\begin{tabular}{|c|c|c|c|c|c|c|c|c|c|}
\hline $\begin{array}{l}\text { Aspects of } \\
\text { comparison }\end{array}$ & Group & Mean & $\begin{array}{l}\text { Mean } \\
\text { diff. }\end{array}$ & $\begin{array}{l}\text { Stand. } \\
\text { Dev. }\end{array}$ & t-value & df & $\begin{array}{c}\text { Sig. } \\
(2- \\
\text { tailed) }\end{array}$ & $\eta 2$ & $\begin{array}{c}\text { Effect } \\
\text { size }\end{array}$ \\
\hline "knowledge & Pre- & 15.37 & $\begin{array}{l}-7.700 \\
\end{array}$ & $\begin{array}{l}1.991 \\
\end{array}$ & -19.897 & 29 & 0.000 & 0.931 & Large \\
\hline
\end{tabular}




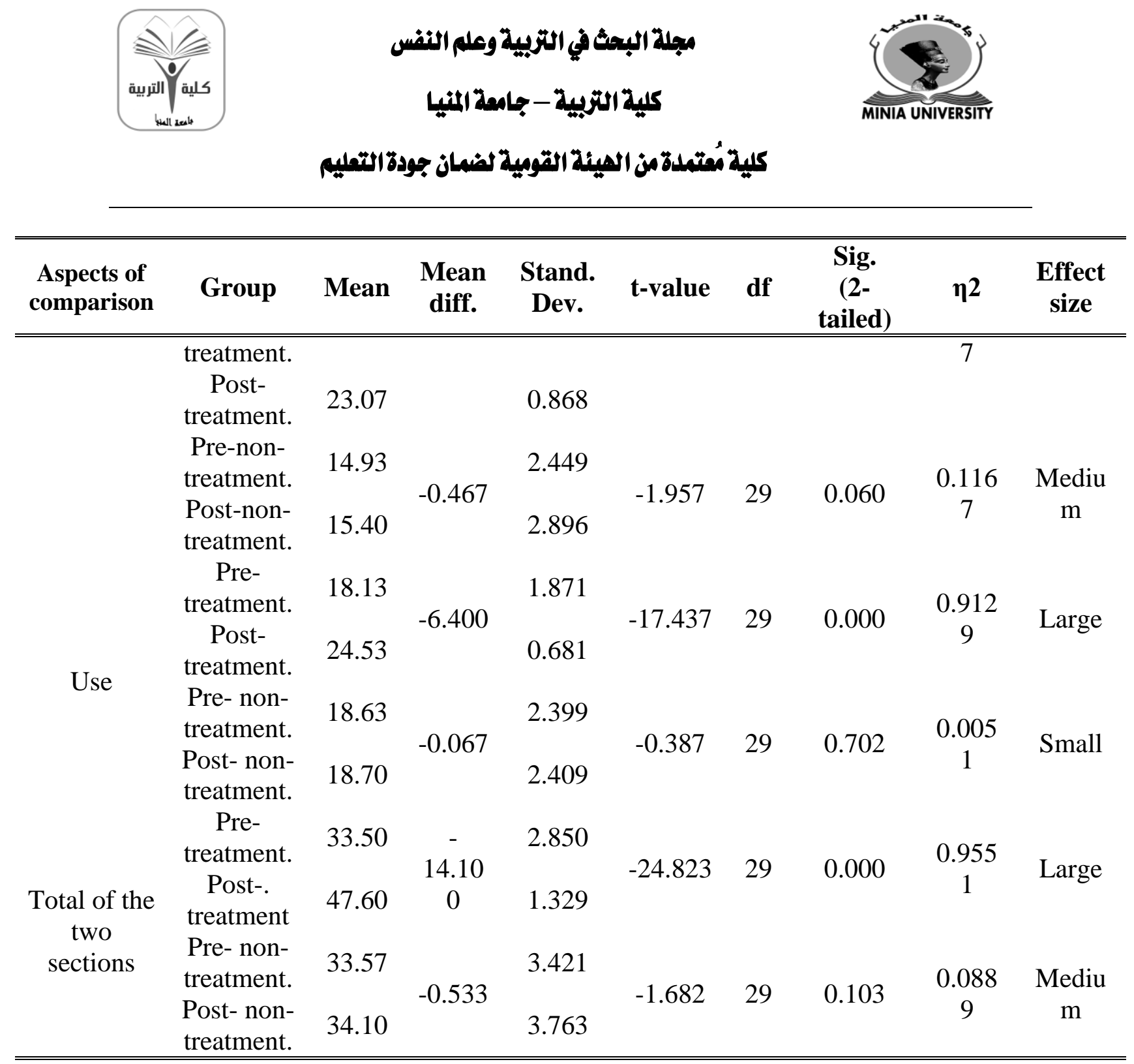

Note. *. significant at the 0.05 level (2-tailed).

\section{Hypothesis 2}

The second hypothesis of the study predicted that there was a statistically significant difference (favoring the treatment group) between mean values obtained by the participants of the treatment and the non-treatment groups on the post- performance of the scale of authorial identity. Statistical analysis of the obtained data showed that the treatment group achieved a higher degree of improvement than the non-treatment group on the scale of authorial identity as t-value (44. 481) is significant at $(0.05)$

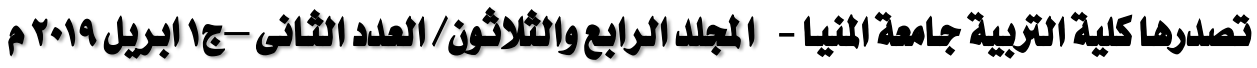

gamel_abd059@yahoo.com http://ms.minia.edu.eg/edu/journal.aspx 

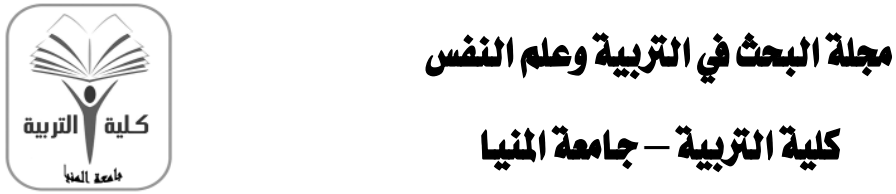

كايلة التزبية - جامعة المنيا

MINIA UNIVERSITY

\section{كلية مُمتمدة من الميئة القومية لضمان جودة التمليم}

level and beyond. Thus, the second hypothesis is confirmed. Table (15) below shows the data obtained to test this hypothesis.

Table (15)

Means, Standard Deviation, $t$ value, $\eta 2$ and effect size on the postperformance of both the treatment and non-treatment group of the authorial identity scale.

\begin{tabular}{|c|c|c|c|c|c|c|c|c|c|}
\hline $\begin{array}{l}\text { Aspects of } \\
\text { comparison }\end{array}$ & Group & No. & Mean & $\begin{array}{c}\text { Std. } \\
\text { Deviation }\end{array}$ & t-value & df & $\begin{array}{c}\text { Sig. } \\
(2- \\
\text { tailed }) \\
\end{array}$ & $\eta 2$ & $\begin{array}{l}\text { Effect } \\
\text { size }\end{array}$ \\
\hline \multirow{2}{*}{ Beliefs } & $\begin{array}{c}\text { Post- } \\
\text { treatment. }\end{array}$ & 30 & 26.23 & 1.382 & \multirow{2}{*}{28.152} & \multirow{2}{*}{58} & \multirow{2}{*}{0.000} & \multirow{2}{*}{0.9318} & \multirow{2}{*}{ Large } \\
\hline & $\begin{array}{c}\text { Post- } \\
\text { nontreatment. }\end{array}$ & 30 & 15.10 & 1.668 & & & & & \\
\hline \multirow{2}{*}{$\begin{array}{l}\text { Discourse } \\
\text { features }\end{array}$} & $\begin{array}{c}\text { Post- } \\
\text { treatment. }\end{array}$ & 30 & 25.83 & 1.315 & \multirow{2}{*}{28.054} & \multirow{2}{*}{58} & \multirow{2}{*}{0.000} & \multirow{2}{*}{0.9314} & \multirow{2}{*}{ Large } \\
\hline & $\begin{array}{c}\text { Post- } \\
\text { nontreatment. }\end{array}$ & 30 & 16.30 & 1.317 & & & & & \\
\hline \multirow{2}{*}{ Obstacles } & $\begin{array}{c}\text { Post- } \\
\text { treatment. }\end{array}$ & 30 & 15.00 & 1.083 & \multirow{2}{*}{3.943} & \multirow{2}{*}{58} & \multirow{2}{*}{0.000} & \multirow{2}{*}{0.2114} & \multirow{2}{*}{ Large } \\
\hline & $\begin{array}{c}\text { Post- } \\
\text { nontreatment. }\end{array}$ & 30 & 13.83 & 1.206 & & & & & \\
\hline \multirow{2}{*}{$\begin{array}{c}\text { Rhetorical } \\
\text { consciousness- } \\
\text { raising }\end{array}$} & $\begin{array}{c}\text { Post- } \\
\text { treatment. }\end{array}$ & 30 & 14.13 & 1.479 & \multirow{2}{*}{15.136} & \multirow{2}{*}{58} & \multirow{2}{*}{0.000} & \multirow{2}{*}{0.7980} & \multirow{2}{*}{ Large } \\
\hline & $\begin{array}{c}\text { Post- } \\
\text { nontreatment. }\end{array}$ & 30 & 9.13 & 1.042 & & & & & \\
\hline \multirow{2}{*}{ Social constructs } & $\begin{array}{c}\text { Post- } \\
\text { treatment. }\end{array}$ & 30 & 17.07 & 2.016 & \multirow{2}{*}{9.947} & \multirow{2}{*}{51.216} & \multirow{2}{*}{0.000} & \multirow{2}{*}{0.6304} & \multirow{2}{*}{ Large } \\
\hline & $\begin{array}{c}\text { Post- } \\
\text { nontreatment }\end{array}$ & 30 & 12.63 & 1.377 & & & & & \\
\hline \multirow{2}{*}{$\begin{array}{c}\text { Total of } \\
\text { dimensions }\end{array}$} & $\begin{array}{c}\text { Post- } \\
\text { treatment. }\end{array}$ & 30 & 98.27 & 2.828 & \multirow{2}{*}{44.481} & \multirow{2}{*}{58} & \multirow{2}{*}{0.000} & \multirow{2}{*}{0.9715} & \multirow{2}{*}{ Large } \\
\hline & $\begin{array}{c}\text { Post- } \\
\text { nontreatment. }\end{array}$ & 30 & 67.00 & 2.613 & & & & & \\
\hline
\end{tabular}

Note. *. significant at the 0.05 level (2-tailed).

To ensure the effectiveness of the weblog- oriented program in improving participants' authorial identity, eta-

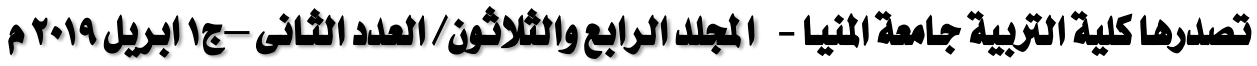

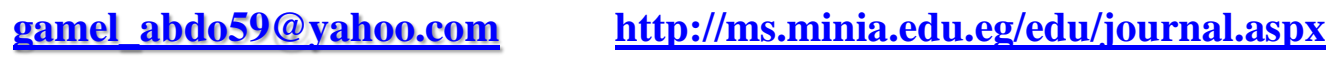



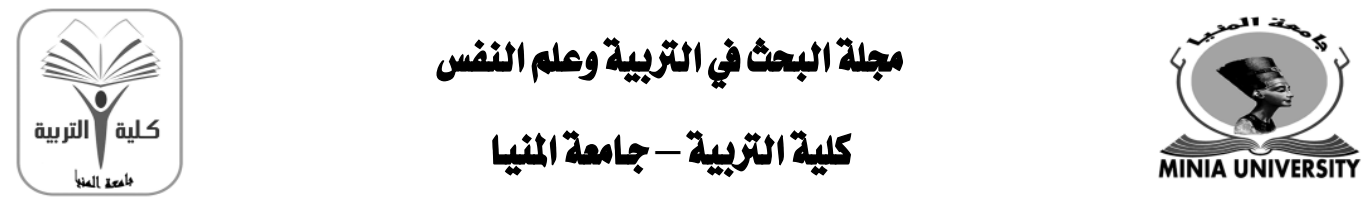

كلية مُعتمدة من الميئة القومية لضمان جودة التمليم

squared formula statistics ( $\eta 2$ ) was used. Cohen et al. (2007:522) pointed out that when eta-squared value $=0.01$, the effect is considered weak, when it $=\mathbf{0 . 0 6}$, the effect is considered medium and when it $=0.14$ the effect is large. As shown in table (15) etasquared value $(\eta 2)$ equals $(0.9715)$ which is considered large. Thus, the weblog- oriented program is considered with high effect in improving EFL senior students' authorial identity.

Additionally, the comparison of the values obtained by the participants of both the treatment and non-treatment groups in the pre-post performance on the scale of authorial identity revealed that the treatment group outperformed the nontreatment group as t-value (43.461) is significant at 0.05 level and beyond. Eta- squared value $(\eta 2)$ equals $(0.9849)$ which is considered large. This is shown in table (16).

Table (16)

Means, Standard Deviation, $t$ value, $\eta 2$ and effect size between mean scores of the treatment and the nontreatment groups on the Pre-Post performance on the authorial identity scale. $\mathrm{N}=\mathbf{3 0}$

\begin{tabular}{|c|c|c|c|c|c|c|c|c|c|}
\hline $\begin{array}{l}\text { Aspects of } \\
\text { comparison }\end{array}$ & Group & Mean & $\begin{array}{c}\text { Mean } \\
\text { diff. }\end{array}$ & $\begin{array}{l}\text { Stand. } \\
\text { Dev. }\end{array}$ & t-value & df & $\begin{array}{c}\text { Sig. } \\
(2- \\
\text { tailed) }\end{array}$ & $\eta 2$ & $\begin{array}{l}\text { Effect } \\
\text { size }\end{array}$ \\
\hline \multirow{5}{*}{ Beliefs } & $\begin{array}{c}\text { Pre- } \\
\text { treatment. }\end{array}$ & 14.63 & \multirow{2}{*}{-11.600} & & \multirow{2}{*}{-28.794} & \multirow{2}{*}{29} & \multirow{2}{*}{0.000} & \multirow{2}{*}{0.9662} & \multirow{2}{*}{ Large } \\
\hline & $\begin{array}{l}\text { Post- } \\
\text { treatment. }\end{array}$ & 26.23 & & 1.382 & & & & & \\
\hline & $\begin{array}{l}\text { Pre-non } \\
\text { treatment. }\end{array}$ & 14.90 & & 1.936 & & & & & \\
\hline & & & -0.200 & & -1.000 & 29 & 0.326 & 0.0333 & Small \\
\hline & $\begin{array}{l}\text { Post-non } \\
\text { treatment. }\end{array}$ & 15.10 & & 1.668 & & & & & \\
\hline \multirow{3}{*}{$\begin{array}{l}\text { Discourse } \\
\text { features }\end{array}$} & $\begin{array}{l}\text { Pre- } \\
\text { treatment. }\end{array}$ & 16.27 & \multirow{2}{*}{-9.567} & 1.484 & \multirow{2}{*}{-26.982} & \multirow{2}{*}{29} & \multirow{2}{*}{0.000} & \multirow{2}{*}{0.9617} & \multirow{2}{*}{ Large } \\
\hline & $\begin{array}{c}\text { Post- } \\
\text { treatment. }\end{array}$ & 25.83 & & 1.315 & & & & & \\
\hline & $\begin{array}{l}\text { Pre-non } \\
\text { treatment. }\end{array}$ & 16.10 & -0.200 & 1.583 & -0.972 & 29 & 0.339 & 0.0316 & Small \\
\hline \multicolumn{10}{|c|}{ 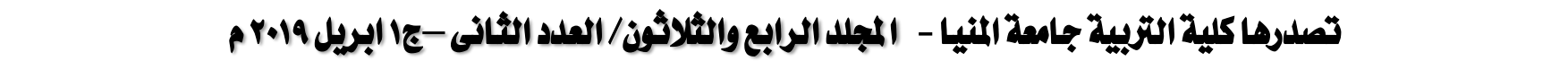 } \\
\hline & el_abdo59 & yahoo. & & http://ms & minia.edı & $\log$ & 1/journ: & aspx & \\
\hline
\end{tabular}



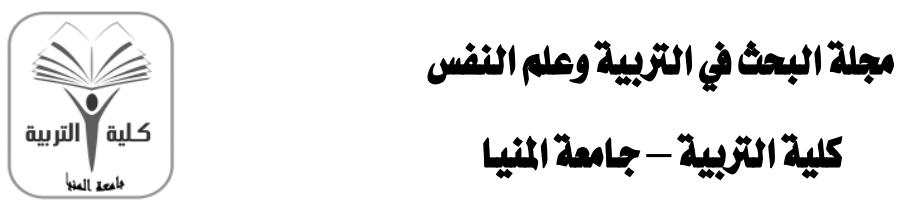

كاية التزبية - جامعة المنيا

MINIA UNIVERSITY

كلية مُعتمدة من الميئة القومية لضمان جودة التمليم

\begin{tabular}{|c|c|c|c|c|c|c|c|c|c|}
\hline $\begin{array}{l}\text { Aspects of } \\
\text { comparison }\end{array}$ & Group & Mean & $\begin{array}{l}\text { Mean } \\
\text { diff. }\end{array}$ & $\begin{array}{l}\text { Stand. } \\
\text { Dev. }\end{array}$ & t-value & df & $\begin{array}{c}\text { Sig. } \\
(2- \\
\text { tailed })\end{array}$ & $\eta 2$ & $\begin{array}{l}\text { Effect } \\
\text { size }\end{array}$ \\
\hline \multirow{3}{*}{ Obstacles } & $\begin{array}{l}\text { Post-non } \\
\text { treatment. }\end{array}$ & 16.30 & & 1.317 & & & & & \\
\hline & $\begin{array}{c}\text { Pre- } \\
\text { treatment. } \\
\text { Post- } \\
\text { treatment. }\end{array}$ & $\begin{array}{l}13.73 \\
15.00\end{array}$ & -1.267 & $\begin{array}{l}1.437 \\
1.083\end{array}$ & -3.597 & 29 & 0.001 & 0.3085 & Large \\
\hline & $\begin{array}{l}\text { Pre-non } \\
\text { treatment. } \\
\text { Post-non } \\
\text { treatment. }\end{array}$ & $\begin{array}{l}13.63 \\
13.83\end{array}$ & -0.200 & $\begin{array}{l}1.245 \\
1.206\end{array}$ & -1.063 & 29 & 0.297 & 0.0375 & Small \\
\hline \multirow{2}{*}{$\begin{array}{l}\text { Rhetorical } \\
\text { consciousness } \\
\text {-raising }\end{array}$} & $\begin{array}{l}\text { Pre- } \\
\text { treatment. } \\
\text { Post- } \\
\text { treatment. }\end{array}$ & 14.13 & -5.000 & $\begin{array}{l}1.279 \\
1.479\end{array}$ & -15.546 & 29 & 0.000 & 0.8929 & Large \\
\hline & $\begin{array}{l}\text { Pre-non } \\
\text { treatment. } \\
\text { Post-non } \\
\text { treatment. }\end{array}$ & $\begin{array}{l}9.03 \\
9.13\end{array}$ & -0.100 & $\begin{array}{l}1.217 \\
1.042\end{array}$ & -0.593 & 29 & 0.557 & 0.0120 & Small \\
\hline \multirow{2}{*}{$\begin{array}{c}\text { Social } \\
\text { constructs }\end{array}$} & $\begin{array}{c}\text { Pre- } \\
\text { treatment. } \\
\text { Post- } \\
\text { treatment. }\end{array}$ & $\begin{array}{l}12.60 \\
17.07\end{array}$ & -4.467 & $\begin{array}{l}1.754 \\
2.016\end{array}$ & -9.376 & 29 & 0.000 & 0.7519 & Large \\
\hline & $\begin{array}{l}\text { Pre- } \\
\text { treatment. } \\
\text { Post- } \\
\text { treatment. }\end{array}$ & $\begin{array}{l}12.47 \\
12.63\end{array}$ & -0.167 & $\begin{array}{l}1.525 \\
1.377\end{array}$ & -0.961 & 29 & 0.344 & 0.0309 & Small \\
\hline \multirow{2}{*}{$\begin{array}{c}\text { Total of } \\
\text { dimensions }\end{array}$} & $\begin{array}{l}\text { Pre- } \\
\text { treatment. } \\
\text { Post- } \\
\text { treatment. }\end{array}$ & $\begin{array}{l}66.37 \\
98.27\end{array}$ & -31.900 & $\begin{array}{l}2.906 \\
2.828\end{array}$ & -43.461 & 29 & 0.000 & 0.9849 & Large \\
\hline & $\begin{array}{l}\text { Pre-non } \\
\text { treatment. } \\
\text { Post-non } \\
\text { treatment. }\end{array}$ & $\begin{array}{l}66.13 \\
67.00\end{array}$ & -0.867 & $\begin{array}{l}3.748 \\
2.613\end{array}$ & -1.887 & 29 & 0.069 & 0.1094 & Medium \\
\hline
\end{tabular}

Note. *. significant at the 0.05 level (2-tailed).

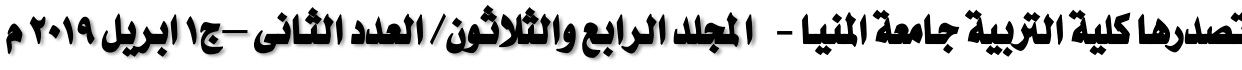

gamel_abdo59@yahoo.com http://ms.minia.edu.eg/edu/journal.aspx 

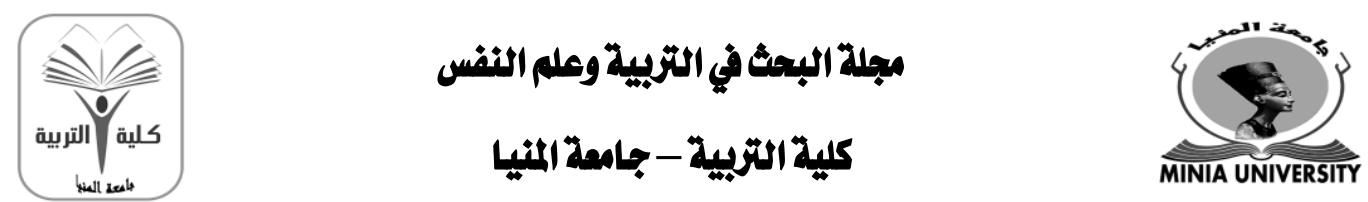

كلية مُتملةة من الميئة القومية لضمان جودة التمليي

\section{Discussion of Results}

The inherent features of the study on the basis of the students' reflections

The participants' first impressions towards the process of setting up a weblog, the prerequisite technological skills and the required blogposts combined feelings of confusion, anxiety with being overloaded and highly challenged. Gradually, through video presentations, modeled examples and handouts, the participants showed improved skills in managing blogpost technically. The other accompanying digital platforms, group Face Book, served as their virtual corner for exchanging queries, materials and enhancements, supporting their on-going reflection and filling any personal gaps. The two web 2.0 digital platforms, weblog and face book, represented online forums for the participants to voice their concerns and scaffold each other through instructor's and peers' constructive feedback.

Through reading, commenting and writing posts on the weblog, the participants assured their ability to learn from each other some writing conventions, develop a repertoire of words relevant to their discipline to be used afterwards in their writing and be enabled to scaffold each other through navigating their writing tasks, processing academic writing knowledge, as well as establishing and negotiating their identities as academic writers. Consequently, the academic writing process has not been considered as classroom-oriented or meaningless tasks anymore, as it became more real because of the availability of real audience, through the weblog, more than their instructor.

The weblog provided the participants with online virtual space to process and rec-construct their academic writing knowledge, identify what counts for being authors, become aware of their purposes of writing, develop their metacognitive skills through monitoring and reflecting on their learning progress, negotiate their identities as academic writers, scaffold each other

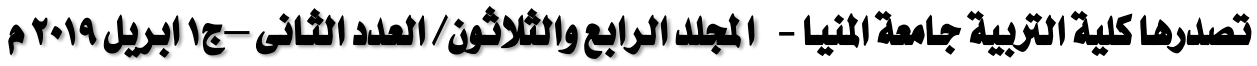

gamel_abdo59@yahoo.com

http://ms.minia.edu.eg/edu/journal.aspx 

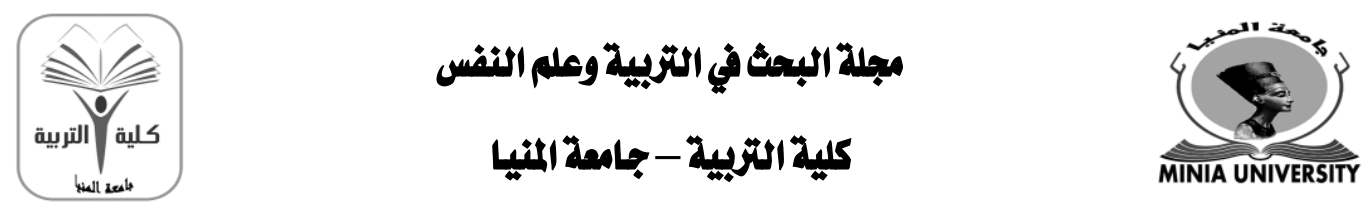

كلية مُتملةة من الميئة القومية لضمان جودة التمليي

through encouragement, praise and offering resources through synchronous and asynchronous online social interaction.

The relation of the present study's results to the results of other conducted studies

Results of studies that coincide with those obtained by the present study. The findings of the present study corresponded with (Hyland, 2002; Pittam et al., 2009; Calvert ,2014 and McCullocha ,Tustinga \& Hamiltonb, 2017) in emphasizing the idea that instruction in authorship should be combined with very concrete instruction on citation, referencing and paraphrasing to encourage students to think of themselves as authors and construct and adopt more authorial identities as academic writers. Moreover, the results of the present study concerning the use of weblogs are consistent with previous research studies (Aljamah, 2012; Vurdien, 2012; Kitchakarn, 2014; Crawford, Mora \& Lengeling, 2016 and Huang, 2016) in which using blogs could enhance students' writing skills and (McCullocha et al., 2017; Dizon \& Thanyawatpokin, 2018 and Listyani, 2018) in sporting collaborative feedback and peer editing.

Results of studies that show the limitations of using weblogs. Some studies showed the limitations of using weblogs as (e.g. lack of feedbacks and correction, passive behavior, distraction, timespent, and computer problems (Aljamah, 2012 and Huang, 2016) and that through the blogpost the students would be engaged with language mechanics rather than with positioning and voice (Jarkas \& Fakhreddine, 2017).

Conclusion

As Web technology becomes an increasingly integral part of language education today, this study shows how blogs with their authentic, interactive and collaborative features can serve as a valuable tool for helping graduate students process and reconstruct academic writing knowledge and negotiate their identity as EFL writers. However, to overcome the limitations of

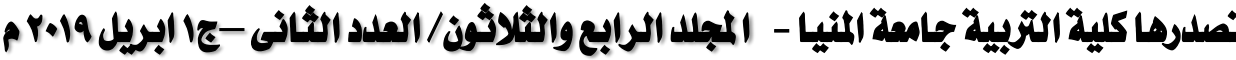

gamel_abdo59@yahoo.com

http://ms.minia.edu.eg/edu/journal.aspx 

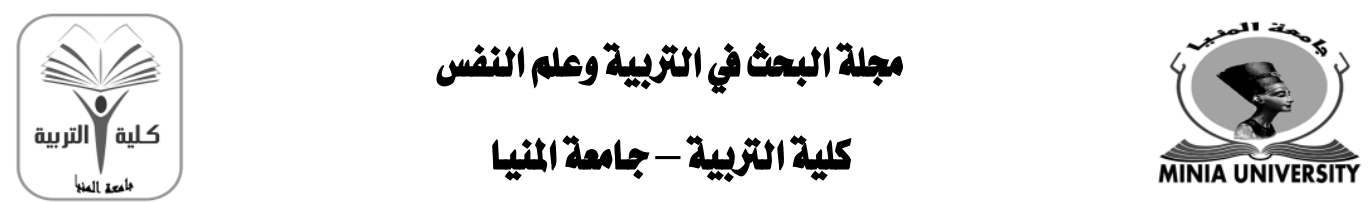

كلية مُعتملة من الميئة القومية لضمان جودة التمليم

blogs in relation to lack of feedback, corrections, time, distraction and computer problems, weblogs are better used to augment instead of replacing traditional writing assignments.

Implications

1- The engagement of blogging in teaching EFL writing is effective for learners' enhancement of academic writing, on condition that it should be accompanied by conventional methods of teaching and much guidance throughout the process on using technology properly.

2- The e-writing pattern of blog makes it much more convenient for the students to read and evaluate each other's writings. Consequently, it leads to developing rhetorical strategies, improving grammar skills, designing paragraphs and essays, revising written works, giving and receiving feedback and participating in peer review activities. Additionally, it provides a learning space for learners to interact, reflect on learning, develops autonomous learning, and improves self-expression.

3- Within the university, academic staff play key roles: acting as role models of authorial academic writers for students; marking and giving feedback on students' academic writing and designing and delivering pedagogic initiatives to help students improve their authorial identity. Moreover, writing courses, focusing on discipline-specific college writing, designed for foreign-language learners are needed.

4- Future interventions to improve students' authorial identity might therefore aim to identify attributes and processes associated with authorial identity, towards a more psychological understanding of authorial identity, to improve their sense of ownership of written work, guide them toward authorial ways of thinking, and help them adopt more authorial writing goals.

5- Future English teachers must be continuously reminded, required and supported to use academic writing across all

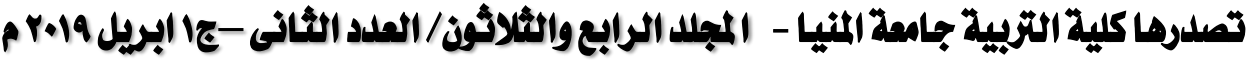

gamel_abdo59@yahoo.com

http://ms.minia.edu.eg/edu/journal.aspx 

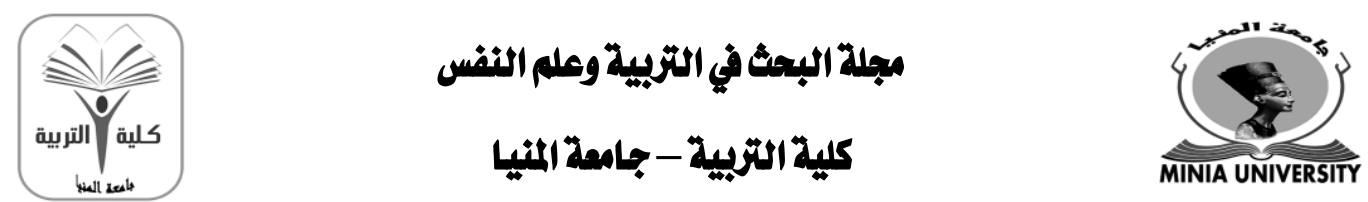

كلية مُعتمدة من الميئة القومية لضمان جودة التمليم

disciplines, being mindful of content-specific lexicon and encouraged to see purposes for writing beyond taking good grades and to regard themselves as writers.

Recommendations

1- There should be prerequisite courses at the college-level that address the sub-skills required for academic writing. Moreover, graduate programs should include some compulsory courses that focus specifically on academic language and style.

2- Curriculum designers should provide a model of teaching materials of academic writing course that focuses on research paper writing and addresses students' needs, curriculum, and also the purposes of English education.

3- Faculty staff should involve students more systematically in activities like journal clubs and seminars where published papers and research findings are discussed. Hence, students' awareness of disciplinary differences in writing would be increased by using different genres of papers, including an argumentative essay, a research paper, a summary, a critique, etc.

4- Faculty staff should promote computer and internet based English teaching in the tertiary classrooms to enhance learners' language skills and encourage peer-support whenever possible.

5- Educators have to incorporate training on contrastive grammar and rhetorical strategies into their writing pedagogy to develop students' metacognitive knowledge about their writing and address the term authorial voice in class discussions, especially when giving feedback on their writing. Moreover, special exercises should be designed to help students shift from performance goals to authorial goals in their writing.

Suggestions for further research

1- The degree to which each of web 2.0 technologies affect student L2 proficiency.

2- The role of individual agency in identity construction.

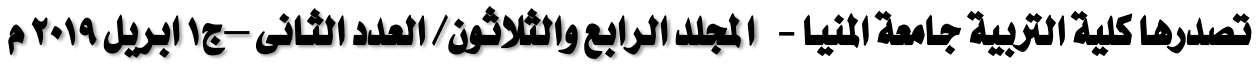

gamel_abdo59@yahoo.com

http://ms.minia.edu.eg/edu/journal.aspx 


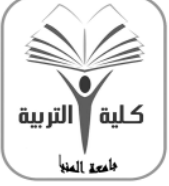

$$
\text { مجلة البعث في التربية وملم النفس التربية - جامعة المنيا }
$$

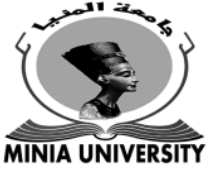

كلية مُعتعدة من الهيئة القومية لشمان جودة التعليم

3- The identity-related features in a wider range of genrespersonal, academic, professional, and public.

4- More qualitative studies with student writers' identities can be conducted according to student nationality, discipline, age, gender, goals, and cultural, linguistic, and educational backgrounds.

5- This study may be replicated with a larger and more diverse sample of EFL students from different governates in Egypt

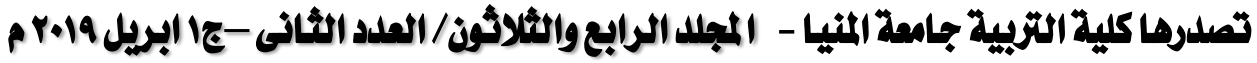

gamel_abdo59@yahoo.com

http://ms.minia.edu.eg/edu/journal.aspx 

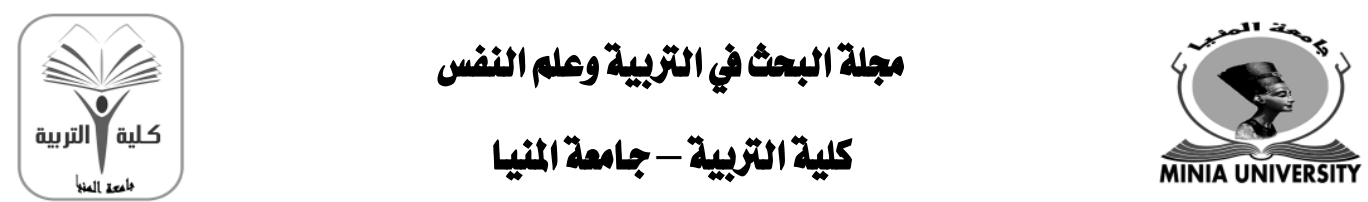

كلية مُقتملةمن الميئة القومية لضمان جودةالتمليم

\section{Reierences}

Akkaya, A., \& Aydin, G. (2018). Academics' Views on the Characteristics of Academic Writing. Educational Policy Analysis and Strategic Research, 13(2), 128-160.

Aljumah, F. (2012). Saudi learner perceptions and attitudes towards the use of blogs in teaching English writing course for EFL majors at Qassim University. English Language Teaching, 5(1), 100-116.

Alméciga, E., Yesid, W., \& Evans, R. (2014). Mentor texts and the coding of academic writing structures: A functional approach. How, A Colombian Journal for Teachers of English, 21(2), 94-111.

Ángel, M., Lucía, N., \& Martínez García, J. (2017). Improving English Language Learners' Academic Writing: A Multi-Strategy Approach to a Multi-Dimensional Challenge. GIST Education and Learning Research Journal, 14, 49-67.

Arslan, R. (2013). Integrating Feedback into Prospective English Language Teachers' Writing Process via Blogs and Portfolios. Turkish Online Journal of Educational Technology-TOJET, 13(1), 131-150.

Aydin, S. (2014). The Use of blogs in learning English as a foreign language. Online Submission, 4(1), 244-259.

Burke, S. (2011). The construction of writer identity in the academic writing of Korean ESL students: A qualitative study of six Korean students in the US. Theses and Dissertations (All). Indiana University of Pennsylvania. Retrieved from http://knowledge.library.iup.edu/etd/635

Calvert, K. (2014). Facilitating the Quest: A Case Study of Three Technologies in an EAPP Writing Classroom. CATESOL Journal, 25(1), 106-117.

Cennetkuşu, N. (2017). International students' challenges in academic writing: A case study from a prominent US university. Journal of Language and Linguistic Studies, 13(2), 309-323.

Cequena, M., \& Salle, D. (2013). Does blogging facilitate the development of students' writing skills. Philippine ESL Journal, 10, 126-147.

Chávez Muñoz, M. (2013). The "I" in interaction: authorial presence in academic writing. Revista de lingüística y lenguas aplicadas, 8, 49-58.

Cheung, K., Elander, J., Stupple, E., \& Flay, M. (2016). Academics' understandings of the authorial academic writer: a qualitative analysis of authorial identity. Studies in Higher Education, 43(8), 14681483.

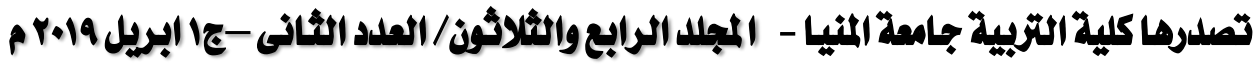

gamel_abdo59@yahoo.com

http://ms.minia.edu.eg/edu/journal.aspx 

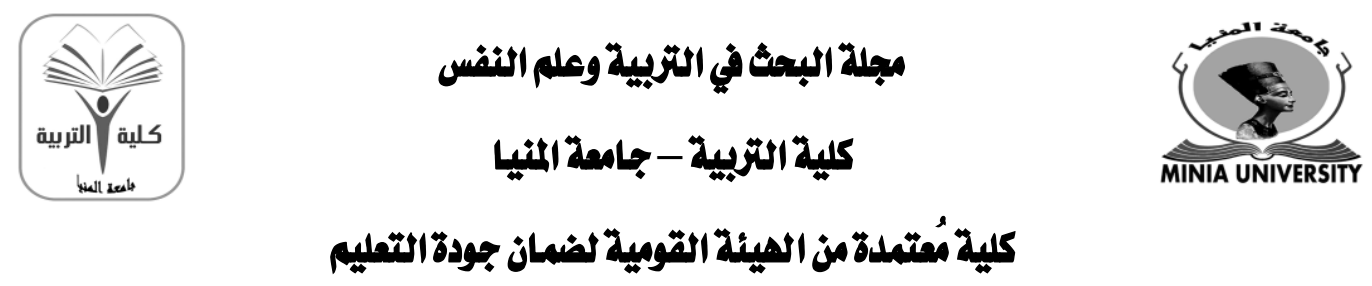

Chong, E. (2010). Using blogging to enhance the initiation of students into academic research. Computers \& Education, 55(2), 798-807.

Cohen, L., Manion, L., \& Morrison, K. (2007). Research methods in education.

Courtney, J. (2007). A Review of Rewriting: How to do Things with Texts. JET, 7(1),74-77.

Crawford, T., Mora Pablo, I., \& Lengeling, M. (2016). Struggling authorial identity of second language university academic writers in Mexico. Profile Issues in Teachers Professional Development, 18(1), 115-127.

Demir, C. (2018). Hedging and academic writing: an analysis of lexical hedges. Journal of Language and Linguistic Studies, 14(4), 74-92.

Dizon, G., \& Thanyawatpokin, B. (2018). Web 2.0 tools in the EFL classroom: Comparing the effects of Facebook and blogs on L2 writing and interaction. The EuroCALL Review, 26(1), 29-42.

Eldaba, A., \& Isbell, J. (2018). Writing Gravity: International Female Graduate Students' Academic Writing Experiences. Journal of International Students, 8(4), 1879-1890.

Ghufron, M., \& Saleh, M., Warsono \& Sofwan, A. (2016). A Model of Research Paper Writing Instructional Materials for Academic Writing Course:" Needs \& Documents Analysis and Model Design". English Language Teaching, 9(3), 1-12.

Grosseck, G., \& Bran, R. (2016). Script towards Research 2.0: The Influence of Digital and Online Tools in Academic Research. World Journal on Educational Technology: Current Issues, 8(2), 132-138.

Hall, M. (2017). Using blogging as a learning tool. Retrieved from https://ii.library.jhu.edu/2013/11/27/using-blogging-as-a-learning-tool/

Hryniuk, K. (2018). Expressing authorial self in research articles written by Polish and English native-speaker writers. Studies in Second Language Learning and Teaching, 8(3), 621-642.

Huang, H. (2016). Students and the Teacher's Perceptions on Incorporating the Blog Task and Peer Feedback into EFL Writing Classes through Blogs. English Language Teaching, 9(11), 38-47.

Hyland, K. (2002). Options of identity in academic writing. ELT journal, 56(4), 351-358.

Inouye, K., \& McAlpine, L. (2019). Developing Academic Identity: A Review of the Literature on Doctoral Writing and Feedback. International Journal of Doctoral Studies, 14, 001-031.

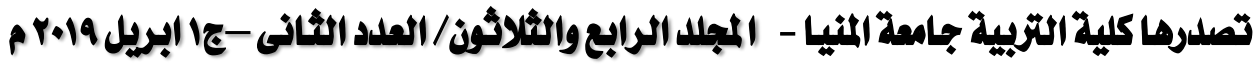

gamel_abdo59@yahoo.com http://ms.minia.edu.eg/edu/journal.aspx 

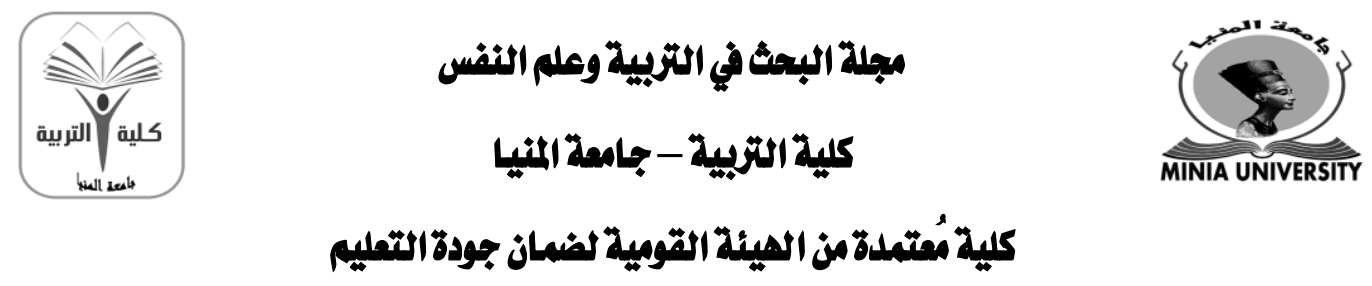

Janks, H. (2012). The discipline and craft of academic writing: Building writing capacity in Institutions of Higher Education. Reading \& Writing-Journal of the Reading Association of South Africa, 3(1), 138155.

Jarkas, N., \& Fakhreddine, J. (2017). The Dance of Voices: A Study on Academic Writing at AUB. EMERGING WRITING RESEARCH FROM THE MIDDLE EAST-NORTH AFRICA REGION, 241-264.

Kim, E. (2017). Academic Writing in Korea: Its Dynamic Landscape and Implications for Intercultural Rhetoric. TESL-EJ, 21(3).

Kitchakarn, O. (2014). Developing Writing Abilities of EFL Students through Blogging. Turkish Online Journal of Distance Education, 15(4), 34-47.

Laughlin, P., \& Winkley, C. (2006). Writing Their World: Promoting a Pedagogy of Authorship in Teacher Education. Online Submission.

Listyani. (2018). Promoting Academic Writing Students' Skills through "Process Writing" Strategy. Advances in Language and Literary Studies, 9(4), 173-197. doi:10.7575/ aiac.alls.v.9n.4p.173

Luehmann, A. (2008). Using blogging in support of teacher professional identity development: A case study. The Journal of the Learning Sciences, 17(3), 287-337.

Matsuda, P. (2015). Identity in written discourse. Annual Review of Applied Linguistics, 35, 140-159.

McCulloch, S., Tusting, K., \& Hamilton, M. (2017). The Role of Networked Learning in Academics' Writing. Research in Learning Technology, 25,1958-1971. http://dx.doi.org/ 10.25304/rlt.v25.1958

Namouz, R., Misher-Tal, H., \& Sela, O. (2017). Improving expressive writing in EFL through blogging. In K. Borthwick, L. Bradley \& S. Thouësny (Eds), CALL in a climate of change: adapting to turbulent global conditions, 222-228.

Pittam, G., Elander, J., Lusher, J., Fox, P., \& Payne, N. (2009). Student beliefs and attitudes about authorial identity in academic writing. Studies in Higher Education, 34(2), 153-170

Rankin-Brown, M., \& Fitzpatrick, C. (2007). A Confluence of Voices Negotiating Identity: An East Coast-West Coast Exchange of Ideas on Writing, Culture, and Self. Online Submission.

Scott, D., Burns, A., Danyluk, P., \& Ulmer-Krol, S. (2018). Evaluating the Effectiveness of Academic Writing Interventions in a Community-Based B. Ed. Program. International Journal of E-Learning \& Distance Education, 33(2).

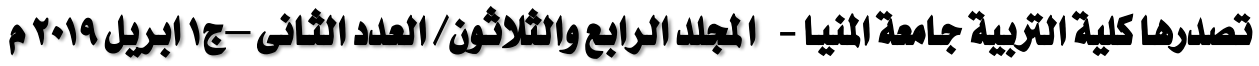

gamel_abdo59@yahoo.com http://ms.minia.edu.eg/edu/journal.aspx 

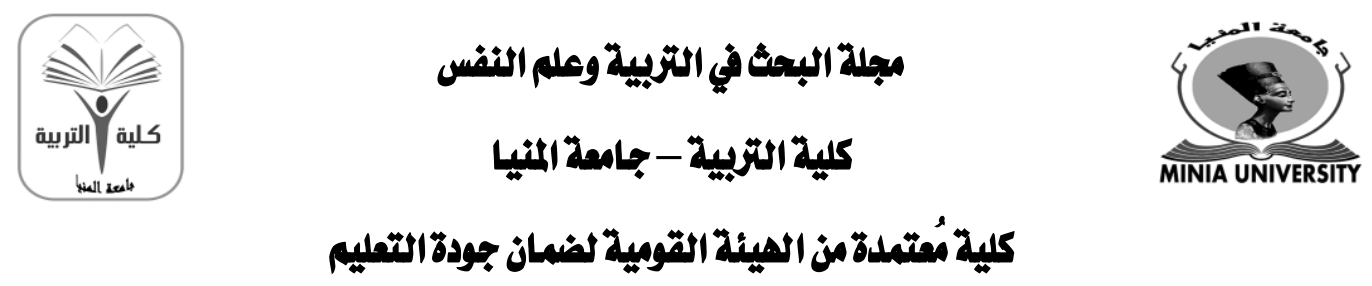

Senel, E. (2018). The Integration of Creative Writing into Academic Writing Skills in EFL Classes. International Journal of Languages' Education and Teaching, 6(2), 115-120. Doi:10.18298/ijlet.2869

Sevcikova, B. (2018). Online Open-Source Writing Aid as a Pedagogical Tool. English Language Teaching, 11(8), 126-142.

Shen, Q. (2013). Use of Blog to Improve English Writing in the Chinese Tertiary EFL Classrooms. English Language Teaching, 6(10), 51-56.

Singh, M. (2017). International EFL/ESL master students' adaptation strategies for academic writing practices at tertiary level. Journal of International Students, 7(3), 620-643.

Street, B. (2015). Academic Writing: Theory and Practice. Journal of Educational Issues, 1(2), 110-116.

Sun, Y., \& Chang, Y. (2012). Blogging to learn: Becoming EFL academic writers through collaborative dialogues. Language Learning \& Technology, 16(1), 43-61.

Thomson, P. (2015). Blogging helps academic writing. Retrieved from https://patthomson.net/2015/12/07/blogging-helps-academic-writing/

Torres, J., \& Anguiano, C. (2016). Interpreting feedback: a discourse analysis of teacher feedback and student identity. Practitioner Research in Higher Education, 10(2), 2-11.

Vurdien, R. (2012). Enhancing Writing Skills through Blogs in an EFL Class. European Association for Computer-Assisted Language Learning (EUROCALL), 20, 155-185.

Wu, G., \& Zhu, Y. (2014). Self-mention and authorial identity construction in English and Chinese research articles: A contrastive study. Linguistics \& the Human Sciences, 10(2).

Yang, X. (2018). A Corpus-Based Study of Modal Verbs in Chinese Learners' Academic Writing. English Language Teaching, 11(2), 122-130. 